\title{
CAPTIVE RHINOCEROSES IN EUROPE FROM 1500 UNTIL 1810
}

\author{
by
}

\section{C. ROOKMAAKER}

\author{
Burgemeester van Tienenweg 37, Diemen, The Netherlands
}

\begin{abstract}
Between 1500 and 1810 ten rhinoceroses have been recorded in Europe, while two others died on their way to Europe. The history of these animals is given here. Eleven specimens belonged to Rhinoceros unicornis, one to Rhinoceros sondaicus. Two doubtful reports are also on record.
\end{abstract}

\section{INTRODUCTION}

Until about the 17th century knowledge of the rhinoceros was limited in Europe to what was handed down by Roman writers, and to more or less incidental information from Africa and Asia. The arrival of some rhinoceroses obviously led to a considerable increase of this knowledge. For this reason it is important to pay attention to the historical data concerning these animals.

Since the arrival of the first rhinoceros in Lisbon in 1515, at least nine of them have been in Europe. After 1810 the number of rhinoceroses in Europe and America quickly increased. A good conspectus of this is given in Reynolds (1960, 1960a, 1964 and 1967), while Kourist (1970) discussed some animals that have been in Europe in the 19th century. In Klös \& Frädrich (1970) we find an enumeration of the African rhinoceroses in captivity on December 31, 1968. This enumeration was later brought up to date until November 1, 1971 (Klös \& Frädrich 1971).

\section{SPECIMENS}

In chronological order the following rhinoceroses have been in Europe since 1515.

The first rhinoceros to come to Europe since the time Philippus Arabs (governing from 244249 A.D.) showed one in Rome (248 A.D.), landed in 1515 in Lisbon, Portugal. This animal has become quite famous, because Albrecht Dürer made two pictures of it; I shall come back to that later. Many data in books not at my disposal are mentioned in Da Costa (1937), to whose book I owe a good deal of the following information. The history of this Great Indian Rhinoceros (Rhinoceros unicornis Linnaeus, 1758) is as follows:

In 1514 the then Portuguese governor in India, Afonso de Albuquerque (1453-1515), tried to obtain permission to build a fort in Diu. For this he had to apply personally to Muzafar II, king of Cambaia, also called Guzerat (about $22^{\circ} \mathrm{N}, 72^{\circ} \mathrm{E}$ ), in whose kingdom Diu was situated. Consequently Albuquerque appointed an embassy consisting of Diogo Fernandes of Beja as first, and James Teixeira as second, ambassador; and further an embassy secretary (Francisco Pais) and an interpreter (Duarte Vaz). This embassy departed in February 1514 from Goa, laden with presents for the king. After some wanderings it met the king on April 16, 1514 in Mandoval (= probably Ahmedabad) (Da Costa, 1937: 9-11).

The negotiations proved unsuccesful and the king of Cambaia gave in return to Albuquerque among others the rhinoceros now under discussion. At that time this animal was still in Champanel, but was brought from there to Surrate by land. It arrived in Surrate on May 16, 1514 and was then handed over to the embassy, which had reached this city already on May 8, 1514. Both embassy and rhinoceros hibernated in Surrate, and did not arrive in Goa until September 15, 1514, after not too long a voyage by means of three small ships. Albuquerque at once decided to send the animal as a gift to Emanuel the Great, king of Portugal (Da Costa, 1937: 12-13).

So this rhinoceros left India, from Cochin, in the beginning of January 1515. It is likely that 
it was accompanied by James Teixeira, one of the ambassadors, and a native Oçem. The journey, that took about 120 days, was made on board the N. ${ }^{a}$ S. ${ }^{a}$ da Ajuda, that possibly arrived in Lisbon harbour on May 20, 1515. Da Costa (1937: 18) concludes this date from the evidence of a letter, written by the very pedantic Valentin Ferdinand of Morovia to a merchant in Neurenberg, with whom he was on friendly terms, at the end of July 1515. In the first part of this letter Valentin gives a description of the rhinoceros; in this he does not only state the above named date of arrival, but also the date of the fight against an elephant, which will be discussed later. The only copy of this letter still in existence, is an Italian one, which today can be found in the Bibliotheca Nazionale Centrale in Florence. In Da Costa (1937: 33-40) we find an English translation of this letter.

So we can safely assume May 20,1515 to be the date of arrival. In the text to the drawing and woodcut of Albrecht Dürer we read May 1, 1513. This inaccurate date has been copied in a great part of the later literature on this subject, which shows the considerable influence of Dürer's work. Loisel (1912, I: 217), probably relying on an anonymously published article (Anonymous, 1855: 202), states 1517 to be the date of arrival, but this is no doubt incorrect.

In Lisbon the animal was possibly kept

"at some outside building of the "Palaçio da Ribeira" or at the neighbouring "Casa da India"" (Da Costa, 1937: 19).

On an inner-court in between these two buildings a fight between the rhinoceros and an Indian elephant (Elephas maximus Linnaeus, 1758) took place on June 3,1515. This was due to Emanuel the Great's desire to test the reports, handed down from antiquity, telling of the eternal hatred these two species of animals foster against each other. Several accounts of this unique spectacle are known, of which $I$ will enumerate the more important. In the first place the fight is briefly mentioned in the above named letter of Valentin Ferdinand who was present at the fight (Da Costa, 1937: 20 and 35). A much more detailed account is given by Damião de Goes in his "Chronica". A French translation of it we find in the "Magasin pittoresque" (Anonymous, 1855: 202-203) and this again is quoted by Loisel (1912, I: 218219). At another place (Schotius, 1603: 1172) Damião de Goes states the date of the fight as being "anno (si bene memini) 1515 vel 16" (Schotius, loc. cit.) ("if I remember correctly in the year 1515 or 1516").

The fight went as follows. The rhinoceros was first brought inside the fence, within which the spectacle was to take place, and was hidden there behind some carpets, so that the elephant would not see it too soon. After this the elephant was introduced, the youngest in Emanuel's possession. Then the carpets were removed and the rhinoceros, kept on a chain by an Indian Oçem, walked in the direction of the elephant. When the latter spotted its rival, it panicked and took to flight, leaving behind its cornoc. It forced an opening through the rather thick latticework of a window and ran away through it, straight to its stable in the Paço dos Estaos, Rossio. The rhinoceros remained quietly in the arena, being the victor (Anonymous, 1855: 202-203).

After this spectacle Emanuel decided to give the rhinoceros to Pope Leo X in Rome, as he wanted to persuade the latter to carry out some of his wishes. He charged João de Pina with the transportation and ordered Ruy Leite, treasurer of the king, to give the following objects to de Pina, who was to present them to the Pope:

"2 silver barrels, 2 silver tankards, 2 silver washing basins, 2 silver jars, 6 golden goblets" (Da Costa, 1937: 28 and 42)

and with the rhinoceros was given a

"gilted iron chain, green velvet collar, with gilted roses and carnations and trimmed with fringe" (Da Costa, loc. cit.).

João de Pina departed from Lisbon in December, 1515 and arrived at Marseille in January, 1516. He landed the rhinoceros on one of the islands of the bay near this town, where Francis I (Valois), the king of France at that time, honoured him with a visit. As a gift of honour the Portuguese offered the king a beautiful horse, who accepted this

"en lui faisant courtoisie de cinq mille écus d'or au soleil" (Anonymous, 1855: 203)

("giving him the courtesy of 5000 gold half crowns").

At the end of January or the beginning of February, 1516, João de Pina and the rhinoceros left for Rome. They did not get far, for the ship on which they journeyed suffered shipwreck due to a storm. This possibly happened

"at the perilous coast (a little northwards of Porto Venere) at the entrance of Spezia"

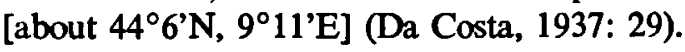




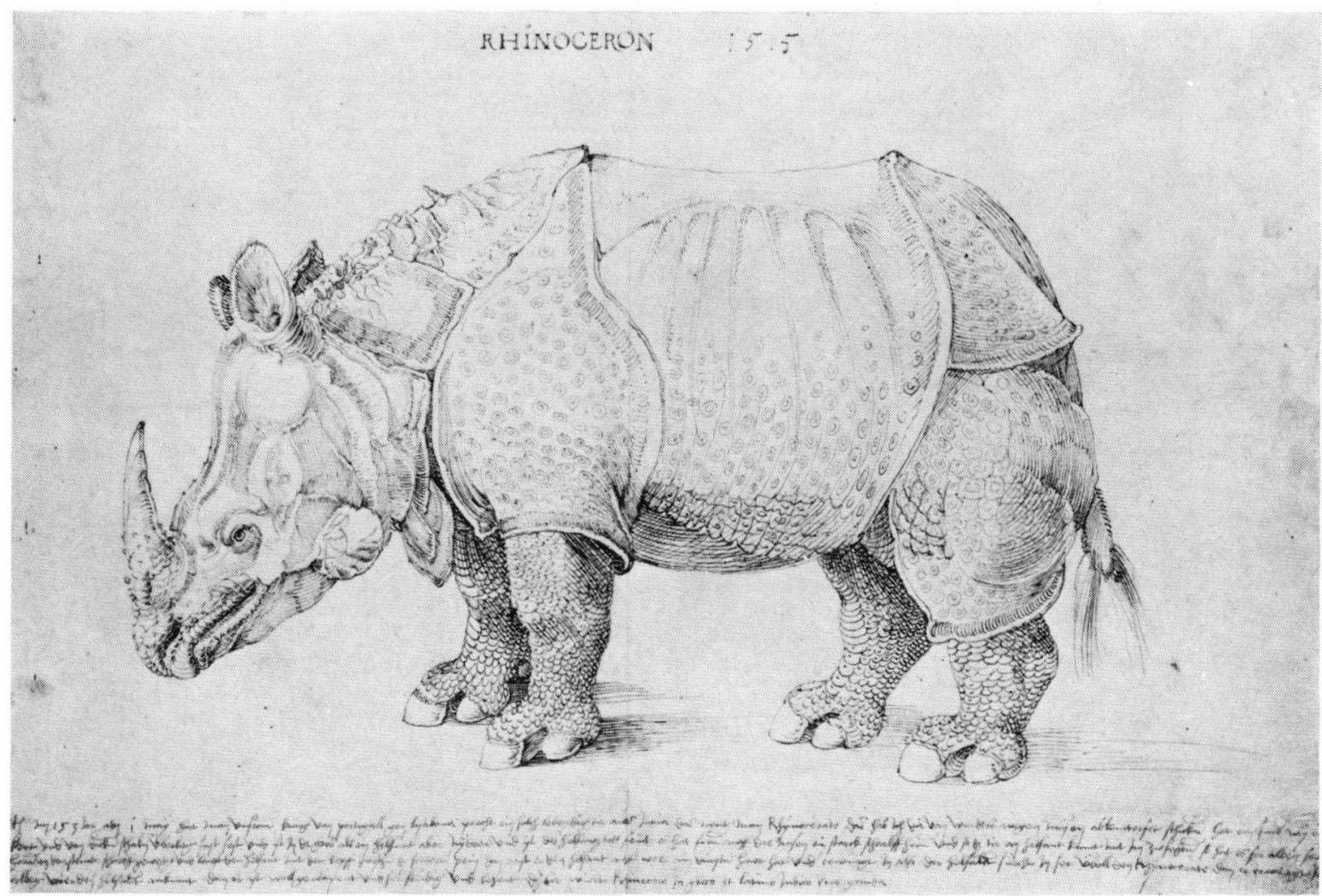

Fig. 1. Drawing by Albrecht Dïrer, 1515, in the British Museum, London (specimen no. I). (Reproduced by courtesy of the Trustees, British Museum, London).

Another version given by James Parsons (1743) and later propagated by Buffon (1754: 190) is that the animal fell into a rage and caused the ship to suffer shipwreck. This is undoubtedly not true.

Damião de Goes (Anonymous, 1855: 203) also reports that the body of the rhinoceros was washed ashore and was stuffed, after which it was sent to Leo X. On August 11, 1516 Emanuel the Great wrote a letter to his ambassador in Rome, Miguel da Silva, in which he ordered him to tell the Pope that much to the regret of the king, the ship with the animal had suffered shipwreck (Da Costa, 1937: 30). Apparently Emanuel did not yet know that the stuffed animal had arrived in Rome. It is questionable whether this really happened.

Of this Indian rhinoceros three representations are known, a drawing (fig. 1) and a woodcut (fig. 2) by Albrecht Diirer (1471-1528) and a woodcut (fig. 3) by Hans Burgkmair (1473-1531), all made in the year 1515. The text to Dürer's drawing and woodcut, which I will later quote in full, shows clearly that Dürer has never seen the animal himself and we may assume that the same applies to Burgkmair, though in his case no proof is available. They had probably seen a sketch of the animal made by a Portuguese artist. $\mathrm{He}$, or perhaps some other Portuguese, sent a letter to a friend in Germany or Antwerp (Da Costa, 1937: 23). Neither the original copy of the sketch nor that of the letter is known. I do not think this letter was the one Valentin Ferdinand sent to Neurenberg, which we have already discussed. I conclude this from the fact that Da Costa (1937) in his discussion of this letter and sketch sent from Portugal does not refer to the letter of Valentin Ferdinand, though he was well aware of its existence.

Besides, it should be noted that Da Costa (1937: 24-25) thinks Dürer's drawing to be the Portuguese sketch, which is most probably wrong. F. J. Cole (1953: 339) thinks that Burgkmair's woodcut resembles the original sketch closest, which may very well be true, though there is no certainty in this matter owing to lack of evidence.

Several states of Dürer's woodcut are known that differ

"entweder in der Ueberschrift mit beweg- 


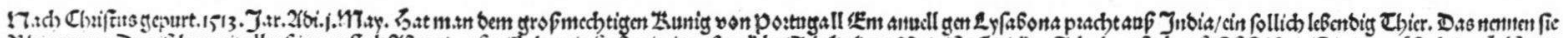

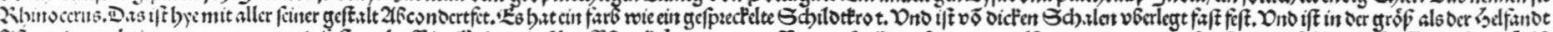

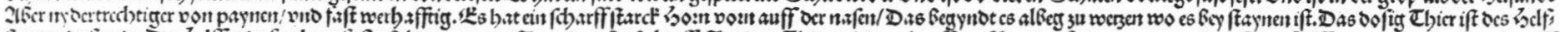

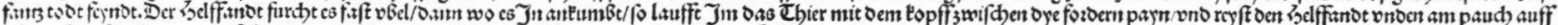

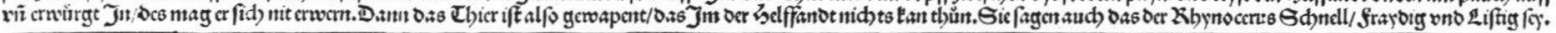

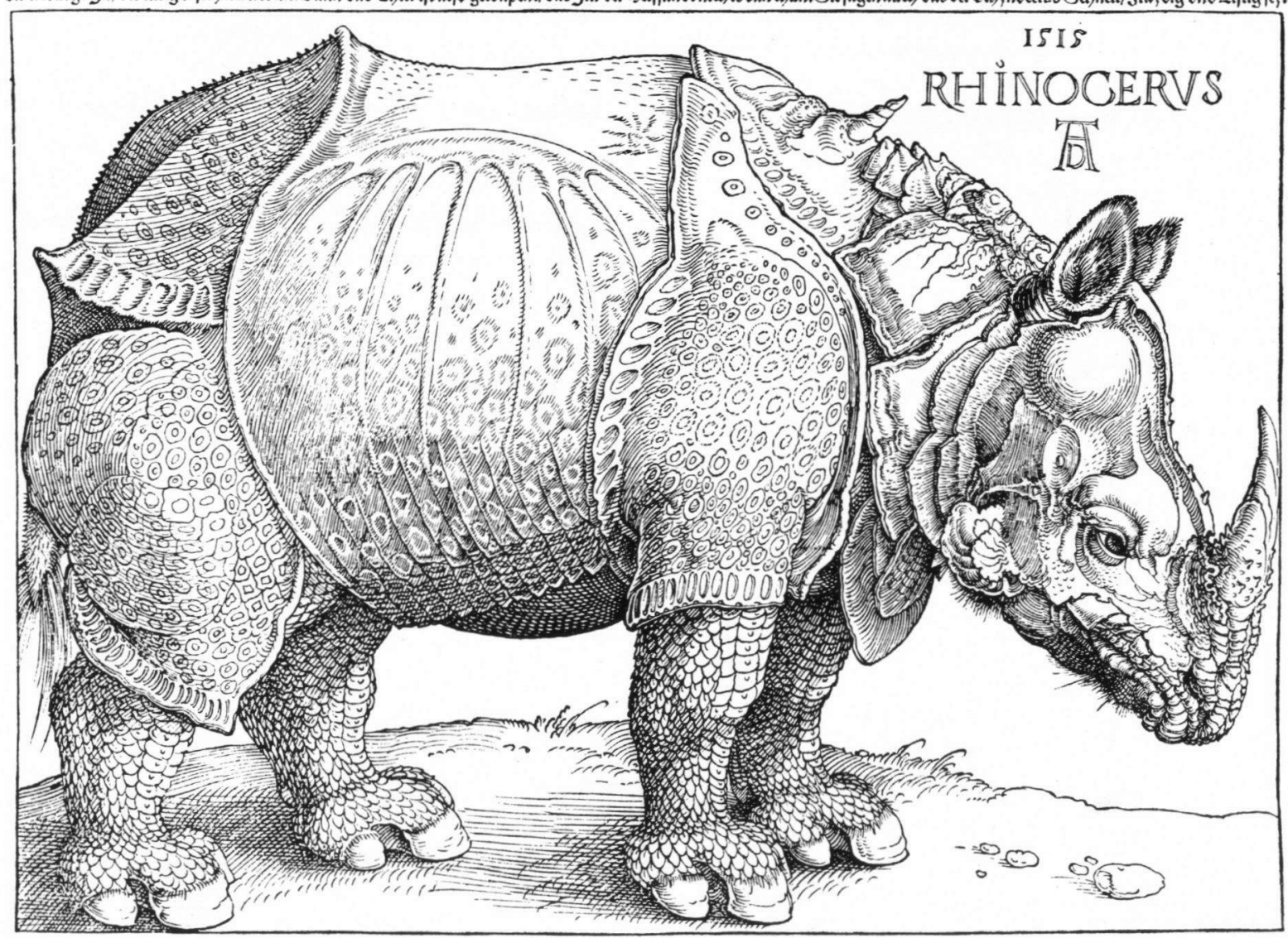

Fig. 2. First state of the woodcut, the "Rhinocerus" by Albrecht Diirer, 1515, in the British Museum, London (specimen no. I). (Reproduced by courtesy of the Trustees, British Museum, London).

lichen Lettern oder in der Beschaffenheit des Holzstockes, auch in den Papieren der Abdrücke" (Hausmann, 1922: 79)

("either in their heading with movable letters or in the nature of the wood used, sometimes also in the kind of paper on which the copy is printed"').

Hausmann mentions nine states, whereas Meder (1932: 254-255), who enumerates only eight, mentions one state (no. 8) which I could not find in Hausmann's enumeration, so there must have been at least ten states.

Dürer's drawing, which can be found in the British Museum (London) and his woodcut, are not similar in every respect. F. J. Cole (1953) sums up the differences between the drawing and the first state of the woodcut:
"The most important is that in the woodcut the body is relatively shorter and heavier, and hence less natural. ..In the woodcut the dorsal horn becomes more prominent, hairs are added to the chin and neck, the shading at the edges of the plicae of the skin is converted into an ornamental pattern, and the median dorsal projection behind the ears is omitted" (Cole, 1953: 340).

It is well-known that Dürer's woodcut was often copied in later zoological literature. A fairly complete enumeration of those who committed plagiarism can be found in F. J. Cole (1953). The drawing, however, does not seem to have been very well-known. Therefore one might say that Duirer's woodcut served as the classic representation of the rhinoceros until about the middle of the 18 th century. As its influence has been con- 
siderable I will quote the text of the first state of the woodcut, after Faensen, 1963: 125.

"Nach Christus Geburt 1513 Jahr, a di 1. Mai, hat man dem grossmächtigen Kunig von Portugall Emanuell gen Lysabona bracht aus India ein solich lebendig Thier, das nennen sie Rhinocerus. Das ist hie mit aller seiner Gestalt abconterfet. Es hat ein Farb wie ein gespreckelte Schildkrot und ist von dicken Schalen uberlegt fast fest. Und ist in der Gröss als der Helfant (Elefant), aber niederträchtiger von Beinen und fast wehrhaftig. Es hat ein scharf stark Horn vorn auf der Nasen, das beginnt es allweg zu wetzen, wo es bei Steinen ist. Das dosig Thier ist des Helfants Todfeind. Der Helfant furcht es fast ubel (fürchtet es sehr). Dann wo es ihn ankummt, so lauft ihm das Thier mit dem Kopf zwischen die vordern Bein und reisst den Helfant unten am Bauch auf und erwürgt ihn, des mag er sich nicht erwehrn. Dann das Thier ist also gewappent, dass ihm der Helfant nichts kann thun. Sie sagen auch, dass der Rhinocerus schnell, freidig und leistig sei."
("On the 1st May, 1513 A.D., there was brought from India to the powerful king of Portugal, Emanuel, at Lisbon, a living animal called rhinoceros. It is represented here. It has the colour of a spotted tortoise and is thickly covered with scales. It is as big as an elephant, but its legs are shorter and it is quite able to defend itself. On the nose it has a sharp and strong horn, which it sharpens as soon as it sees some stones. This clumsy beast is a deadly enemy of the elephant who dreads it tremendously. When it gets near the elephant, it attacks it on the chest charging with the horn between the elephant's front legs. This cannot defend itself and the rhinoceros tears it to pieces and kills it. It is also stated that the rhinoceros is quick, alert and crafty." (cf. also Parsons, 1743: 525 and Da Costa, 1937: 25)). The texts to the later states do not differ much from this one. The text to the drawing, (written in $33 / 4$ lines) however, deviates considerably from the above quotation (printed in 5 lines) (Hausmann, 1922: 79). In connection with this we

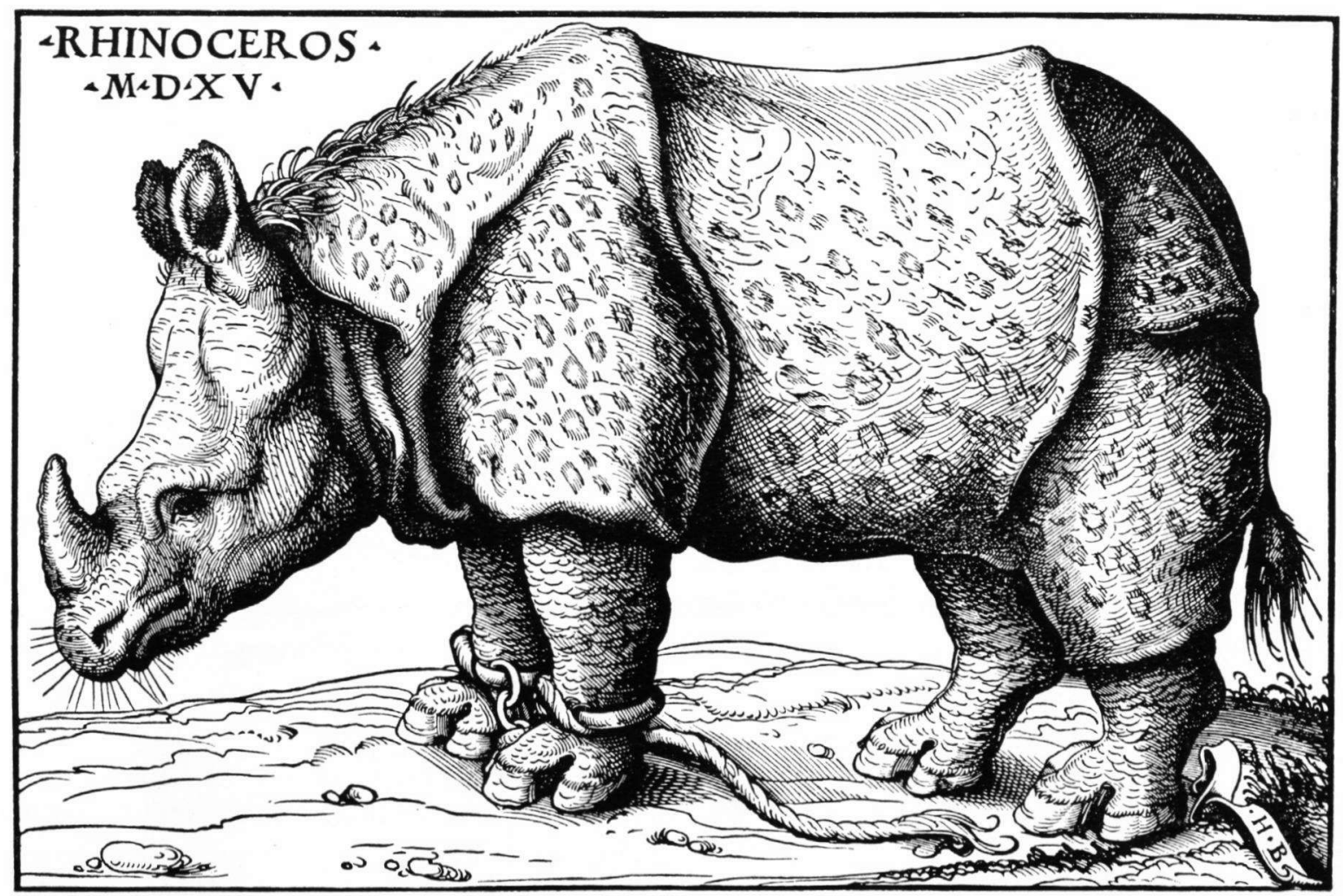

Fig. 3. The rhinoceros woodcut of the rhinoceros by Hans Burgkmair, 1515, in the Graphische Sammlung Albertina, Vienna (specimen no. D. (Reproduced with permission of the Graphische Sammlung Albertina, Vienna). 
should take into account that the drawing was made prior to the woodcut.

In the text of the drawing we read "our king" instead of the "powerful king" and "ein Krot" instead of "ein gespreckelte Schildkrot". Besides, the fact that the rhinoceros was smaller in size than the elephant is not explained and the last line of the woodcut ("It is also stated that the rhinoceros is quick, alert and crafty") is omitted. In the woodcut text no mention is made of the animal being called Rhinoceros in Greek and Latin and "ganda" in India. The order of the sentences is also slightly different (Dodgson, 1938: 4849). As the text of the drawing calls Emanuel I "our king", it is possible that this is the translation of the letter sent to Dürer from Portugal (Dodgson, 1938: 46). Also important is the fact that the date of arrival of the rhinoceros in Lisbon that was first said to be 1513 (on the drawing '153'), was changed to 1515 on the Hondius edition of the woodcut (in Hausmann (1922: 81) this is no. 7, in Meder (1932: 254) no. 6).

Finally I will consider the hornlet that Diirer drew on the shoulders of the rhinoceros and that has later become known under the name of "Diirer-hornlet". It is possible that the rhinoceros that was in Lisbon in $\mathbf{1 5 1 5}$ had in fact such a hornlet, as it is not uncommon for rhinoceroses to have extra horns. I know of three cases in which rhinoceroses had an extra horn in about the same position as Dürer drew his.

a. The female specimen of the square-lipped rhinoceros (Ceratotherium simum simum (Burchell, 1817)), that arrived in San Francisco from Umfolozi on November 26, 1963 (Klös and Frädrich, 1970: 244-245), had a hornlet about $8,5 \mathrm{~cm}$ in length at the same spot as the Dïrer-hornlet (Hediger, 1970; gives also a further description of the hornlet).

b. E. M. Lang (1961: 370) writes:

"Ich kenne mehrere Panzernashörner, die exakt an derselben Stelle Hautauswächse tra. gen" (Lang, loc. cit.)

('I know of several Indian rhinos that have excrescences of the skin on the same spot."). He also mentions that the female Indian rhinoceros, that Frank Buck sold to the Bronx zoo in New York on May 24, 1923 (Reynolds, 1960: 27) had a similar hornlet on the forehead.

c. Col. W. H. Broun (1905) shot a female black rhinoceros (Diceros bicornis (Linnaeus, 1758)) "west of the Jambeni mountains, no, th-east of Mount Kenia"

in August 1904, that had apart from the two usual horns two extra horns, of which one was

"'between the ears and the other about 4 inches (= $10 \mathrm{~cm})$ farther back".

These instances show that it is possible that our rhinoceros had in fact a Dürer-hornlet on its shoulders. The strange thing is that on the woodcut of Burgkmair the hornlet is not depicted. As the latter represents the rhinoceros more realistically, I tend to think that Dürer only imagined, either consciously or unconsciously, the hornlet to be there.

In 1515 Hans Burgkmair, too, made a woodcut (fig. 3) of which only one copy is known, that is kept in the Graphische Sammlung Albertina at Vienna. It differs essentially from the one Diirer made; this woodcut depicts more hair on the snout in comparison with Diirer's work, the ribs on the back and the hornlet on the shoulders are not to be seen and the neck is covered with hair instead of scales (Dodgson, 1938: 55). Besides the rhinoceros on this woodcut looks much more natural than the bizarre, scale-covered animal Diirer depicts. Even the rope around the front-legs is there (Panofsky, 1955: 192).

\section{II}

In a Dutch translation of the five books of Plinius Secundus (1769) the translator, Th. v. Brussel, added among others the following quotation from Laurentius S. Surius (1522-1578),

"In 't Jaar 1581 wierden tot Lisbona, als de Koning van Spanje, Philippus aldaar was, een Olyphant met een Rhinoceros gebracht uit Indien, dewelke den Koning mede nam na Madrid in Spanje." (Plinius, 1769: 161), ("In the year 1581 an Elephant with a Rhinoceros were brougth from India to Lisbon, at the time Philippus, King of Spain, was there; the King took both these animals with him to Madrid in Spain.").

Approximately the same text is found in Linschoten (1644: 70). The history of this animal, which probably belonged to the Indian species (Rhinoceros unicornis), is unknown to me.

Camerarius the younger (1595, pls. 4 and 5) published two pictures (fig. 4) of an Indian rhinoceros. It is clear that these two miniature engravings made by Hans Sibmacher (Cole, 1953: 344) are not based on Dirrer's woodcut, as the Diurer- 

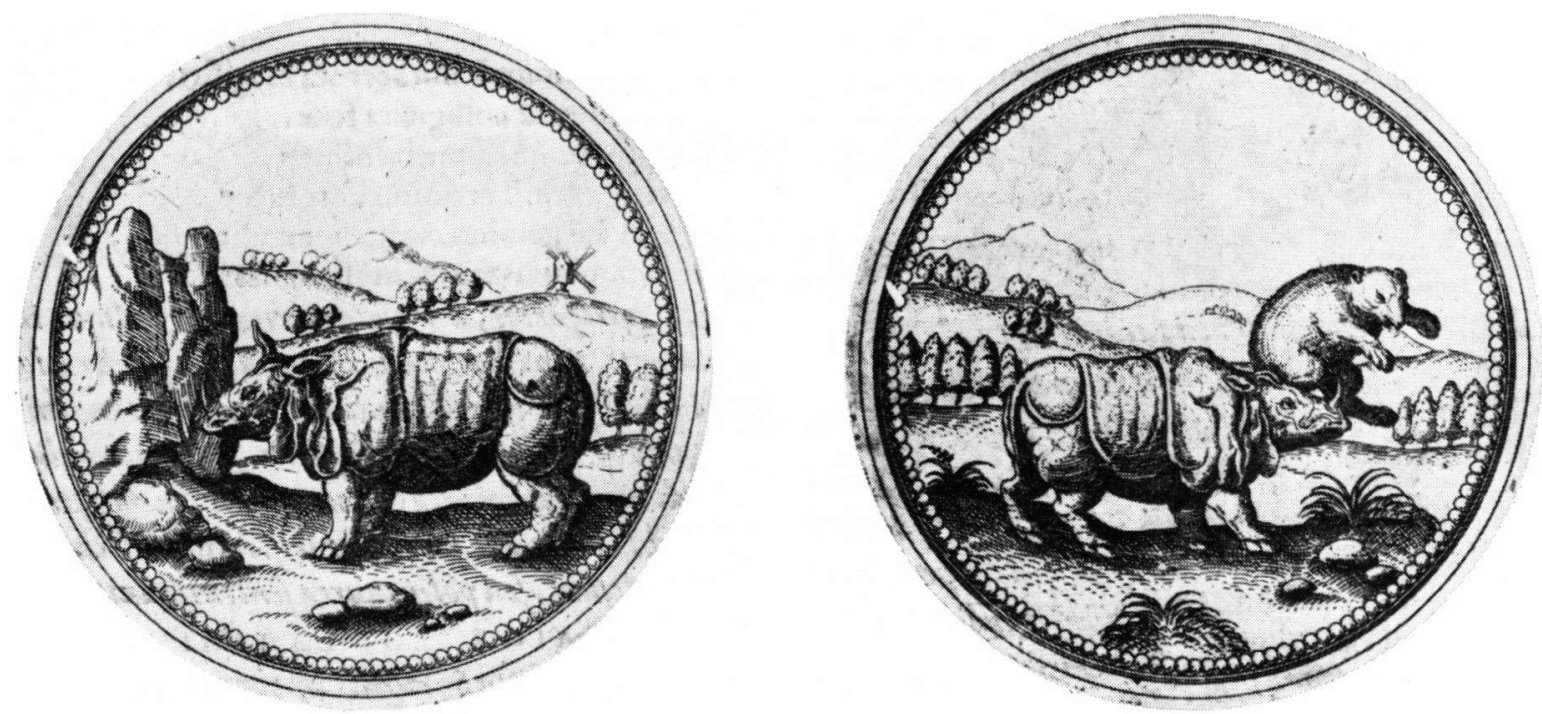

Fig. 4. The two miniature engravings of a rhinoceros in Spain; published by Camerarius the younger (1595, pls. 4 and 5) (specimen no. II). (Photo: Bibliotheek der Rijksuniversiteit in Leiden, Holland).

hornlet is missing and the animal looks much more natural. Camerarius says that he received these engravings 'a short time ago' from Spain. It is probable that the animal depicted here is the same as the one mentioned in Plinius (1769) and Linschoten (1644).

\section{III}

Most information of the animal now under consideration is given by John Evelyn in his diary, under the entry of October 22, 1684:

"I went with Sir William Godolphin to see the rhinoceros or unicorn, being the first that I suppose was ever brought into England. She belonged to some East India merchants and was sold (as I remember) for above $£ 2.000$." (Evelyn, 1908: 360).

John Ray (1693: 123) tells us additionally that this specimen was led about England in 1684 and 1685 and that its food consisted of hay, turniptops and corn (cf. also Gowers, 1952: 288).

This Indian rhinoceros (Rhinoceros unicornis) was probably female, as Evelyn talks of a 'she'. It is impossible to assess precisely when this animal arrived in England or when it died. I am, however, under the impression that it did not arrive long before October 22, 1684 and that it died at the beginning of 1686 at the latest, mainly because several writers have observed that it did not live long (among others Schreber, 1835: 292).

A possible representation of this animal is found on a painting by Jacob Bouttats (Bayerische Staats-Gemälde Sammlung, inv. no. 2217), dated 1700. The rhinoceros is almost certainly drawn from life, but, apart from the date, there are no indications as to whether this is really the above discussed animal.

\section{IV}

This specimen does not really belong in this chronological enumeration, as it never arrived in Europe. According to George Edwards (1758) an officer, whose name is unknown to me, made a sketch of a rhinoceros in 1737. This animal was aboard the 'Shaftsbury', a ship of the East India company, under command of Captain Matthew Bookey. Though this sketch has not been traced, it probably depicted an Indian rhinoceros (Rhinoceros unicornis), as Edwards (1758: 25) mentions the fact that it resembles the specimen the representation of which he published (see no. VI and fig. 12).

The officer who made the sketch also presented us with a small description that was published by Edwards (1758: 25-26; also quoted by Buffon, 1754: 175). It appears from this description that the animal died on its way to Europe, that it was a male rhinoceros, 7 feet $(=213 \mathrm{~cm})$ in height though not yet three years old. Buffon (1754: note on p.176) doubts, with reason in my opinion, whether a three year old animal can be $213 \mathrm{~cm}$ high. The average height of the shoulders of a 
full-grown Indian rhinoceros ranges between 160 and $200 \mathrm{~cm}$ and an almost three year old male specimen in the Basel zoological garden ('Rudra') was only $157 \mathrm{~cm}$ high (Lang, 1961: 406). As it seems that a three year old Indian rhinoceros cannot be $213 \mathrm{~cm}$ high, one of the two data mentioned by Edwards must be incorrect. It cannot be traced which of the two it is.

\section{V}

In Bengal a certain Humphrey Cole, director of a factory of the East India company at Patna, came into possession of this young rhinoceros. He sent it to London on the 'Lyel', a ship under command of Captain Acton; it arrived there on June 1, 1739. At that time already more than $£ 1.000$ had been spent on this two year old animal. On the 15th this male Indian rhinoceros (Rhinoceros unicornis) was shown to the public at Eagle Street, Red Lyon Square in London (Parsons, 1743: 528). In a pamphlet entitled "A natural history of Four-footed Animals. Of the rhinoceros. 12 pp. 1 pl." the first representation of this animal was published. This happened "according to Act of Parliament" on July 3, 1739 by J. Duke, as appears from the text below the picture. Supposedly, the representation was made by I. Carwitham.

On October 10, 1739 a second representation (size $33 \times 33 \mathrm{~cm}$ ) of it was published in London (Carus \& Engelmann, 1861: 1392). In $1743 \mathrm{Ja}$ - mes Parsons re-issued this drawing together with two others by way of illustration to his essay on the natural history of the rhinoceros (fig. 5). This leads Sir W. Gowers (1952: 288) to conclude that the animal did not live very long. because its appearance would have changed in the course of those four years. Although I do not think this is necessarily true, it must be admitted that virtually nothing is known about the further life of this rhinoceros. Only L. J. Fitzinger (1836) makes the following, rather vague remark:

"Jenes von 1739 wurde durch beynahe ganz Europa geführt" and "Das Rhinoceros von 1739 starb in der Menagerie zu Versailles" (according to Giese, 1962: 138).

("The one of 1739 was conducted through almost the whole of Europe" and "The rhinoceros of $1739 \mathrm{died}$ in the Menagerie at Versailles").

No other writer confirms this information.

The food consisted of 7 pounds of rice, mixed with 3 pounds of sugar, together with hay and green-fodder; it was fed three times a day. It only drank water (Parsons, 1743: 529).

\section{VI}

Abundant literature exists about the animal now to be considered, a female Indian rhinoceros (Rhinoceros unicornis). Much information about the first years of its life can be found on a poster, issued on the occasion of its stay in Leipzig
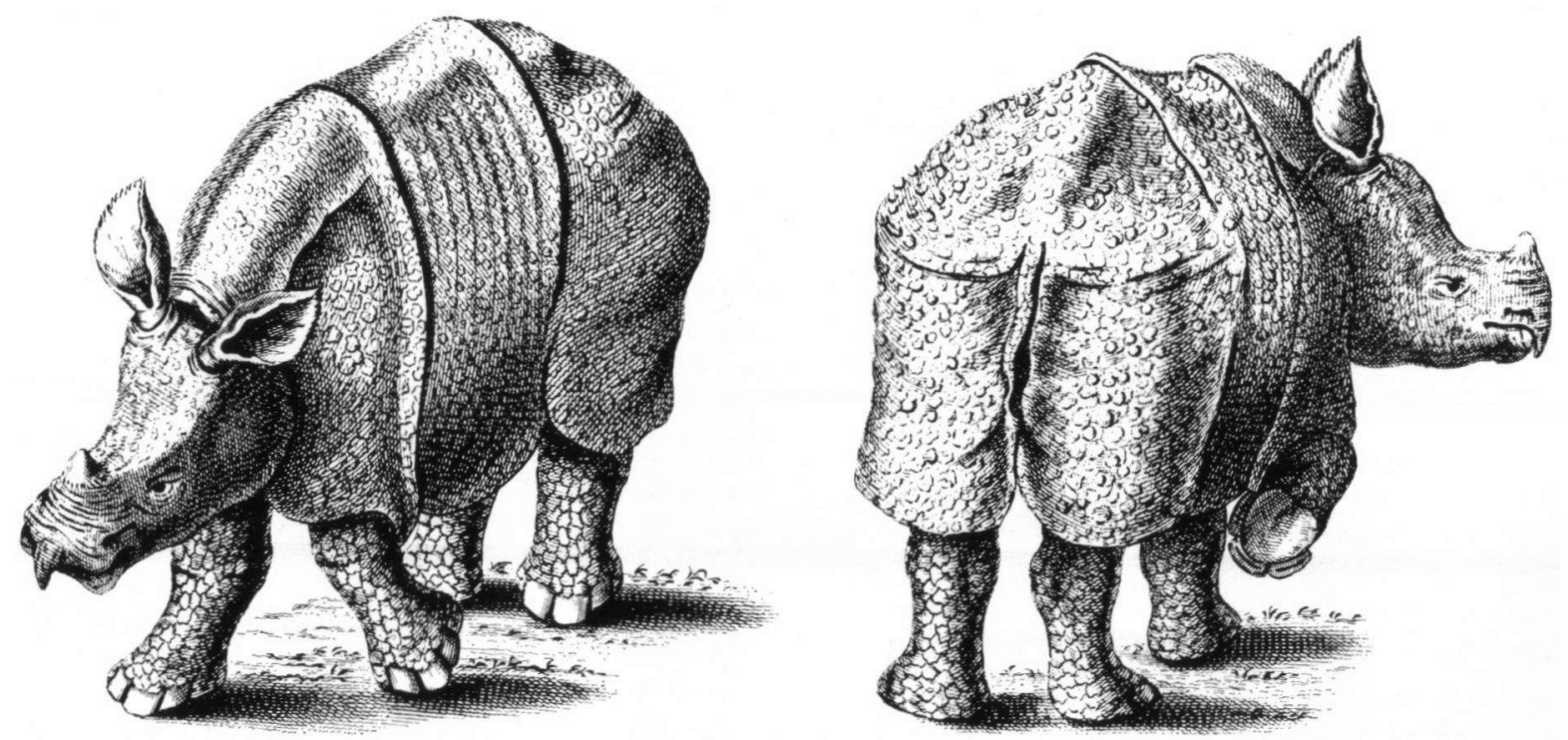

Fig. 5. The Indian rhinoceros that was exhibited in London in 1739. Drawn, engraved and published by James Parsons (1743, tab. 2) (specimen no. V). (Photo: Artis-library, Amsterdam). 
(1747). On this poster we read that it was caught with snares when it was one month old on the territory of the Great Mogol, also called Assam. By that time the mother had already been killed with arrows. The poster also tells us that after its being caught, it was kept as a domestic animal for two years (Petzsch, 1935: 374 and 1954: 51).

From Assam the rhinoceros was brought to Bengal, where it was embarked on a ship the name of which ('Knabenhoe") is mentioned on the reverse side of a tin commemorative medal struck at Neurenberg in 1748 (Petzsch, 1935: 374, 1954: 52 and 1961: 110). The ship was under the command of a Dutch captain, Douwe Mout van der Meer. In the various publications, the name of this man was spelled in many different ways. Since he was called Douwe Mout van der Meer in the archives of the city of Leiden, Holland, this probably was his correct name. He was born on the 12th of April, 1705 (Muller, 1876) and was married to Elisabeth Snel (W. Downer, in litt., August 9, 1971).

The two or three years old rhinoceros arrived in London in 1741 (Parsons, 1743). From there it was immediately transported to Holland, where already on May 25, 1741 a print, made by $\mathrm{H}$. Oster, was published (Carus \& Engelmann, 1861: 1393). Unfortunately I could not find a copy of it. In September 1741 the animal was in Amsterdam. This can be inferred from the diary of Jacob Bicker Raye, in which he wrote that he went to look at the animal in that month (Beyerinck \& de Boer, 1935: 91-92).

This rhinoceros serves as background to two engravings in a book about the skeleton and muscles of man, written by Bernardus Siegfried Albinus (1697-1770) and published in 1747. These two pictures (Albinus, 1747, pls. 4 and 8) were both made by Jan Wandelaar (1690-1759) in 1742, which appears from a sentence below the pictures,

"prostat Leidae Batavorum apud J. \& $\mathbf{H}$. Verbeek, Bibliop. 1742"

("sold in Leiden by J. \& H. Verbeek in 1742"),

and from the text to plate 4 (fig. 6). Albinus did not at all object to this strange background. He preferred it to devised ornaments (Albinus, 1747, text to plate 4).

According to Sir W. Gowers (1952: 289) the rhinoceros stayed in Neurenberg during the following years. However, this assertion is nowhere confirmed, as far as I know. It is much more probable, that it remained in Holland from 1741 until about 1746, as Douwe Mout van der Meer was a Dutchman. But again, I could find no confirmation of this. At any rate, in 1746 Douwe Mout van der Meer and the rhinoceros went on a trip via the more important German and French towns. The animal, aged about eight years at the time, was transported during the trip on a

"voiture couverte, trainée dans les mauvais chemins quelque fois par vingt chevaux" (Ladvocat, 1749: 10)

("covered wagon that sometimes had to be pulled by twenty horses when the roads were bad").

The first town they visited was Berlin, where it was exhibited in a fishstand on the Spittelmarkt. It was escorted by

"ein holländischer Kapitän, D. J. Hout" (Klös, 1969: 17)

("a Dutch captain, D. J. Hout");

this name is certainly a degeneration of Douwe Mout van der Meer. It seems likely that Friedrich August II (1712-1786), elector of Sachsen as well as king of Poland, saw the animal there. To see it, he paid twelve ducats on April 26, 1746 and six more the next day (Klös, 1969: 17). The next town they visited was Frankfurt an der Oder, as appears from a speech delivered by Carolus Augustus à Bergen on the 16th of October 1746, in which he stated that a rhinoceros was to be seen at the "last fair" in that place. In that time every year three 'fairs' (Messen) took place in Frankfurt an der Oder: one in spring, one in summer and one in autumn. We cannot be sure to which of the three C. A. à Bergen was referring.

On April 6, 1747 J. M. Barth (1747) wrote to a certain "good friend" that the animal arrived in Regensburg a few weeks before. As he unfortunately does not mention an exact date, the only conclusion to be drawn is that the rhinoceros arrived before April 6, 1747 in Regensburg. Next, it went, together with Douwe Mout van der Meer, to Dresden. According to data supplied to me by the Staatsarchiv in Dresden (in litt., March 18, 1972), it arrived on April 5, 1747. On April 19, 1747 it was taken to the 'Reithaus' and was again viewed by Friedrich August II and his wife (cf. also Petzsch, 1935: 372 and 1954: 51).

From here it was brought straight to Leipzig. The rhinoceros was exhibited at the 'JubilateMesse' there, that lasted from April 23 to 30. 


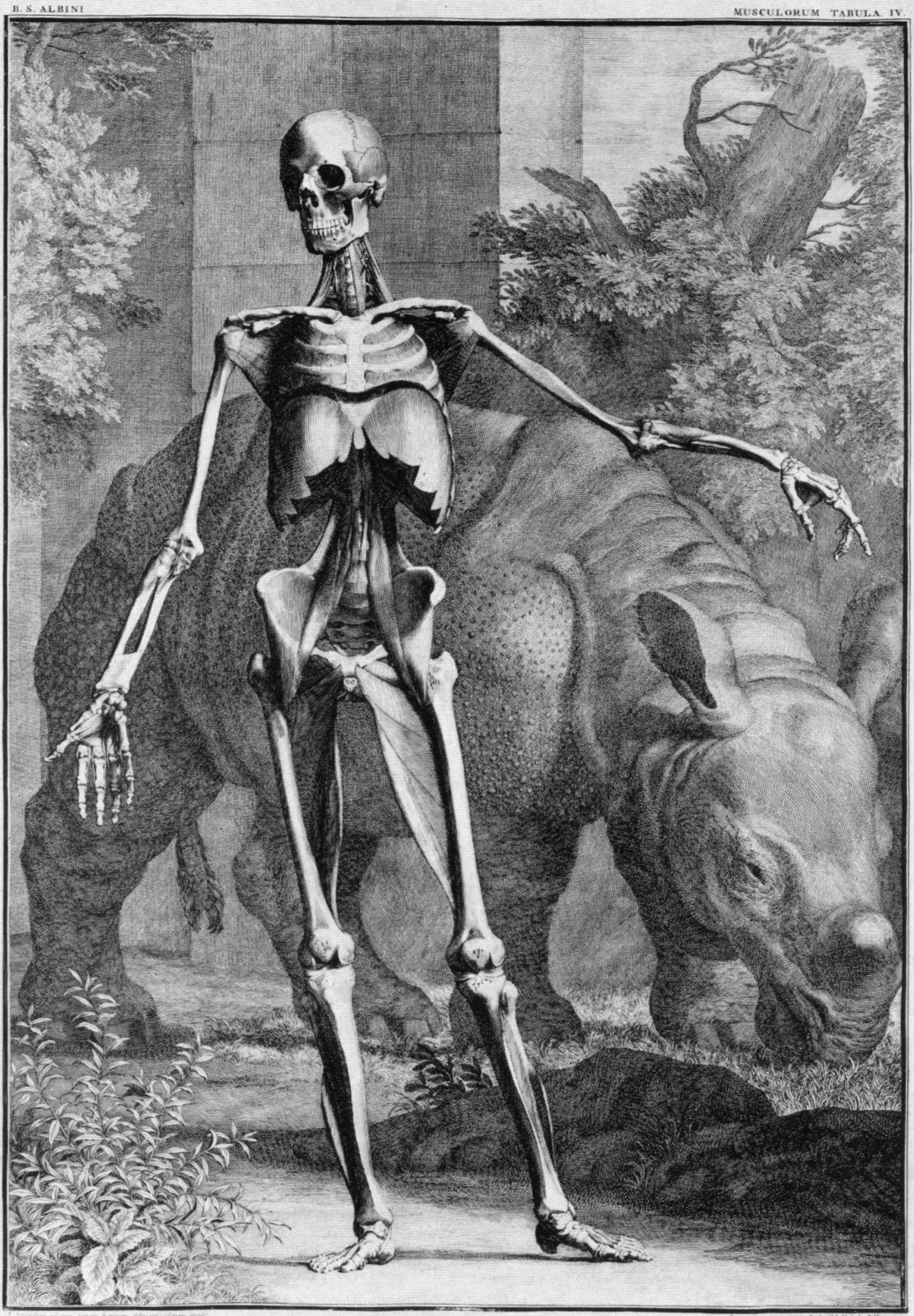

Fig. 6. A representation of a human skeleton with a rhinoceros in the background, made $_{i}$ by. $\mathbf{J a n}_{4}$ Wandelaar $46: 59 \mathrm{pM}$ 1742, published in Albinus (1747, pl. 4) (specimen no. VI). (Photo: Library of the University of Amsterdam)ia free access 
1747 (Stadtarchiv Leipzig, in litt., April 17, 1972, according to "Salomon Riemer. Fortsetzung von Vogels Leipzigschen Jahrbuch, Bd. 2 (1738-1754), S.661"). On the occasion of this visit F. G. Freytag (1747) wrote a booklet, in which he summarized all the knowledge people had at that time of rhinoceroses. There was also a poster published in Leipzig, the text of which was quoted by $\mathbf{H}$. Petzsch in 1935 (Petzsch, 1935: 373); in Petzsch (1954: 51) a representation of the poster was given as well. On this poster is mentioned, apart from the life history of the rhinoceros, that

"Dieses Thier kan von 9. Uhr frühe biss Mittag um 12. Uhr und Nachmittag von 2. biss 6. Uhr Abends gesehen werden. Hohe Standes Persohnen geben nach hohen Belieben. Andere einen halben Gulden, und vier Gro- schen nachderr der Platz ist" (Petzsch, loc. cit.)

("this animal can be viewed from 9 to 12 a.m. and from 2 to 6 p.m.; people with a high position pay as their discretion dictates, others pay half a guilder, and 4 groschen depending on what seats they take").

A bit further we read that

"dieses Thier sich nur ein 10. bis 12. Tage hier aufhalten wird" (Petzsch, loc. cit.)

("this animal will stay here only 10-12 days"). On the upper part of the poster we find a representation on which the animal is depicted sideways, with hardly any background.

The same representation (this time with a background) we find on two anonymous etchings in the Rijksprentenkabinet (RPK) in Amsterdam,

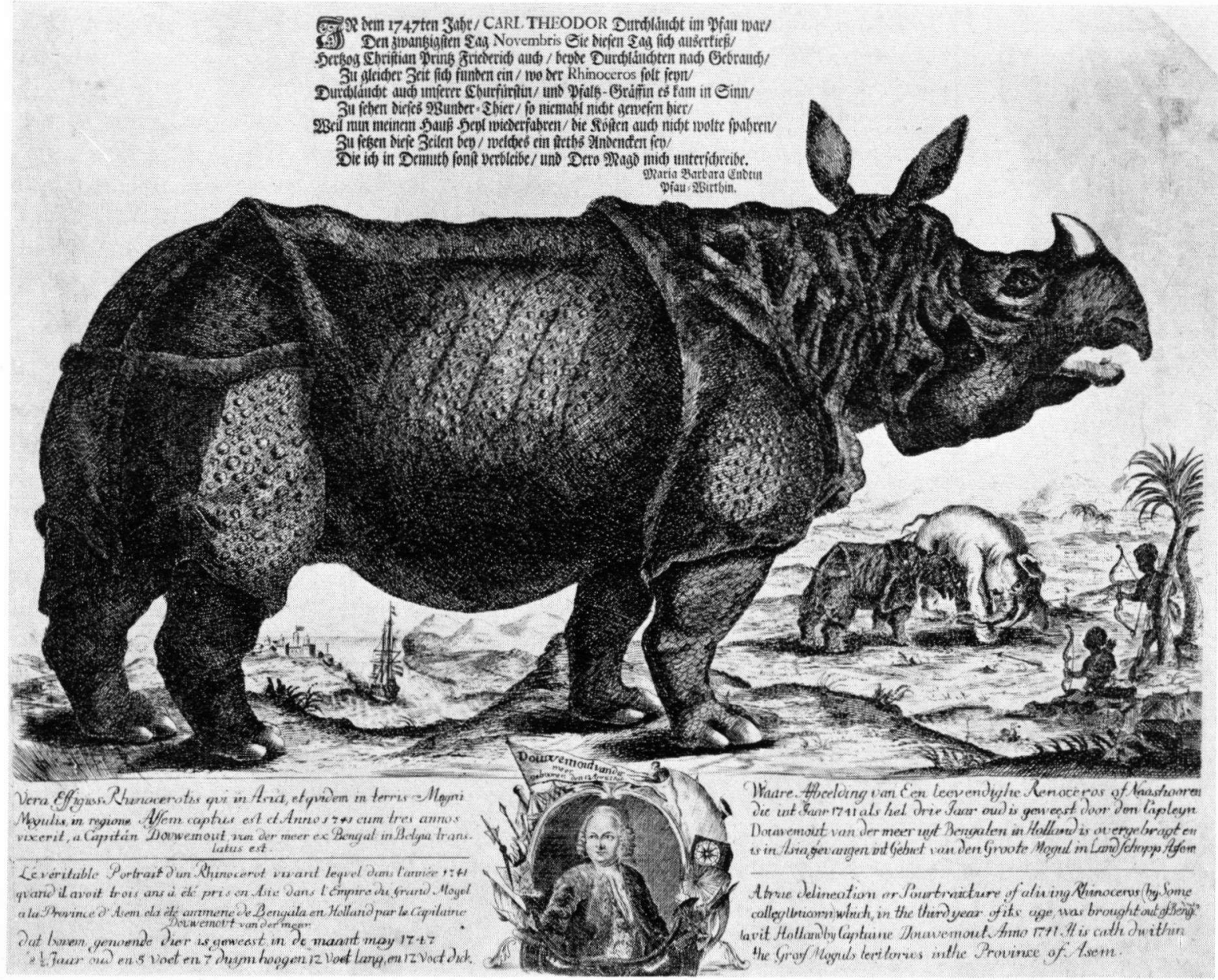

Fig. 7. Anonymous etching of the animal that travelled through Europe from 1741 until 1751. Kept in the Rijksprentenkabinet, Rijksmuseum, Amsterdam (cat. no. FM 3786) (specimen no. VI). (Photo: Rijksmuseum, Amsterdam). 
Holland, one of which is reproduced here (fig. 7; RPK cat. no. FM 3786). These two etchings are not exactly alike; the most striking difference is that the German poem that can be seen above the rhinoceros on the here reproduced etching, is missing on the other one. Unfortunately it is not known when they were made. It is possible that this did not happen before 1747, as might appear from a sentence at the bottom left, in which the measurements of the rhinoceros in May 1747 are mentioned. The German poem, too, mentions a date, namely November 20,1747 , but this poem was possibly added later. I would like to draw your attention to the rhinoceros in the background, fighting with an elephant, which oddly enough is provided with a Duirer-hornlet on the shoulders: the influence of Dürer's woodcut can still be noticed.

The above mentioned German poem was written by Maria Barbara Endtin, the landlady in the 'Pfau' in Neurenberg (Muller, 1876). It appears from the poem the rhinoceros could be seen in the Pfau in Neurenberg on November 20, 1747. I could not find any other proofs concerning its stay in that town.

Sir W. Gowers (1952: 289) states that the animal in Neurenberg

"was painted in 1747 by the accomplished animal painter and delineator J. D. Meyer" (Gowers, loc. cit.).

It is true that we find in Johann Daniel Meyer's (1756) book two plates (pls. 29 and 30) of the rhinoceros, but these are not original. In plate 29 we see the same representation that we have seen on the Leipzig-poster and in the two anonymous etchings in the Rijksprentenkabinet in Amsterdam. The animal in the background of plate 29 and that on plate 30 are both copies of the work of James Parsons (1743, tab. 2), that has been discussed above (specimen no. V, see fig. 5). It is, however, possible that Meyer made these plates owing to the visit of the rhinoceros to Neurenberg.

In May and June 1748 it was shown in Augsburg. Johann Elias Ridinger (1698-1767) has made a few drawings and an etching of it there, as appears from the letter-press below the etching (fig. 8). As far as I know, this etching was not published until 1768 (Ridinger, 1768, pl. 53). In the year 1748 the rhinoceros also went to Stuttgart. On the occasion of its stay there some tin commemorative medals about the size of a halfcrown were ordered in Neurenberg. Of this there exist at least two different versions. Both carry a representation of the animal on the front, while on the back a short biography of it is told. The one version shows the head of the animal turned to the left (Petzsch, 1935: 374 and 1954: 52), while on the other it is turned to the right (Gee, 1952: 401, Coste, 1946: 125 and Petzsch, 1954: 52). We cannot be sure when exactly the animal was in Stuttgart. Ladvocat (1749: 6) states that the animal was already there on May 6, 1748. As this date does not accord with the dates given by $\mathrm{Ri}$ dinger (1768, pl. 53) for its stay in Augsburg. I am inclined to doubt it. It is, however, certain that after Stuttgart, Reims (France) was visited.

Before describing its trip through France, I first want to discuss a remark made by Petrus Camper (1782). In his book about the two-horned African rhinoceros (Diceros bicornis) he states several times, that in Leiden (Holland) he saw a female one-horned specimen in 1748. Almost certainly the above described animal is meant, though the year 1748 seems unlikely owing to the trip it made that year. Unfortunately it cannot be traced whether Camper erred concerning the date or whether it was really in Leiden in 1748 . If the latter is the case, then it must have travelled to Holland either between Neurenberg and Augsburg or between Augsburg and Stuttgart. Camper (1782: 139) mentions the fact that he drew the animal several times in Leiden and modelled it in clay. Only the clay model is known to me: it is kept in the Rijksmuseum van Natuurlijke Historie in Leiden, where it has been since February 8, 1822 (fig. 9).

At the end of the year 1748 the rhinoceros went on a tour through France. It was still escorted by Douwe Mout van der Meer. A circumstantial account of this part of its journey we owe to Gustave Loisel (1912). Coming from Stuttgart, the rhinoceros arrived in Reims at the end of 1748; it left this town on Sunday, December 30, 1748 (Loisel, 1912, II: 278-279). From there it went straight to Versailles, where Louis XV (1710-1774) wanted to buy it for his menagerie. He refrained from buying it, however, owing to the enormous amount of money $(100,000$ crowns) that was asked for it.

Then it was shown at the St. Germain fair in Paris, where it was measured and studied by Ladvocat (1749: 3) on February 7 and 8, 1749. D'Argenson wrote in his 'Mémoires, VI (21 novembre 1749), p.77' about 


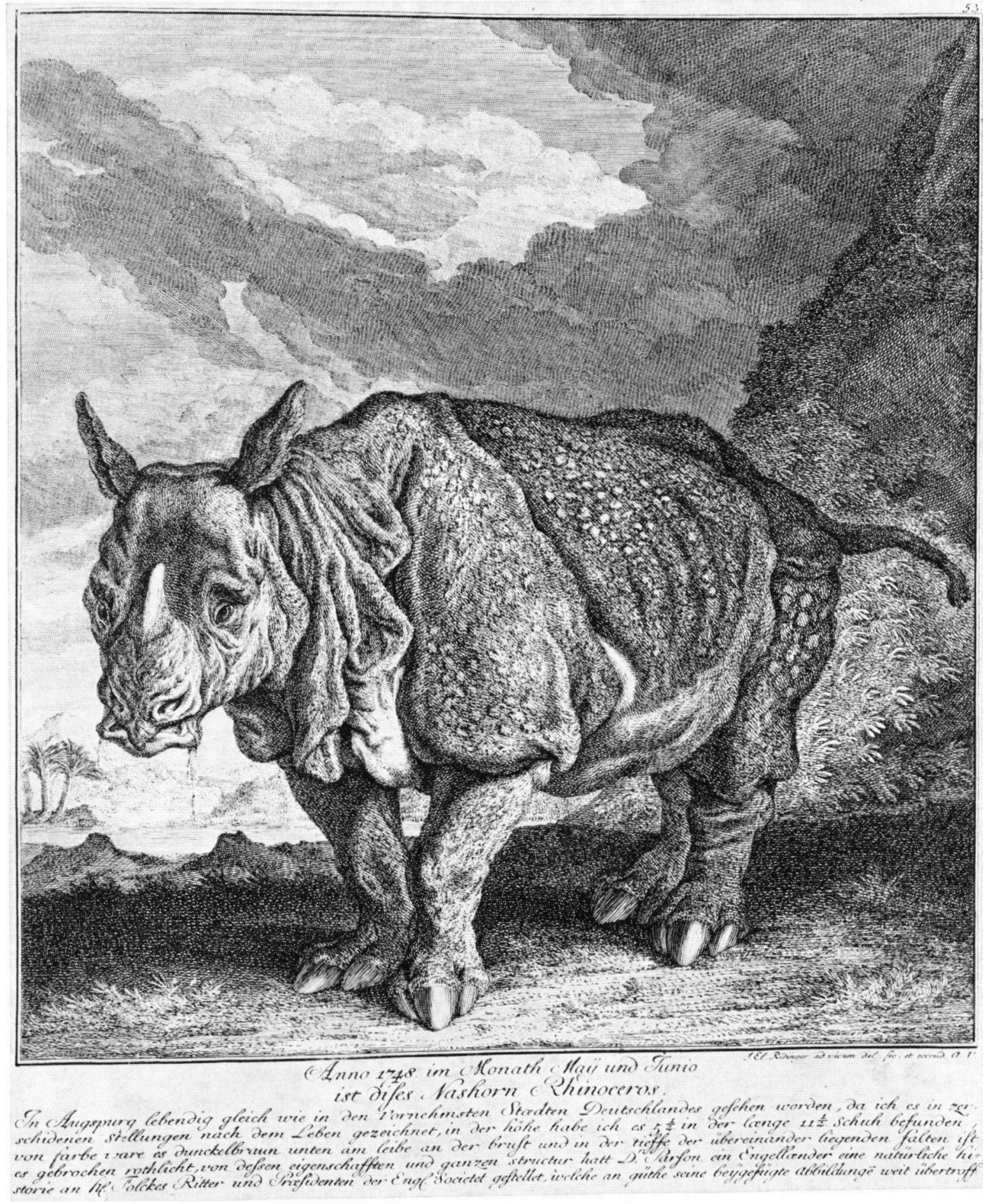

Fig. 8. Etching of the rhinoceros in Augsburg in 1748, made by Johann Elias Ridinger and published by him (1768, pl. 53) (specimen no. VI). (Photo: Artis-library, Amsterdam). 


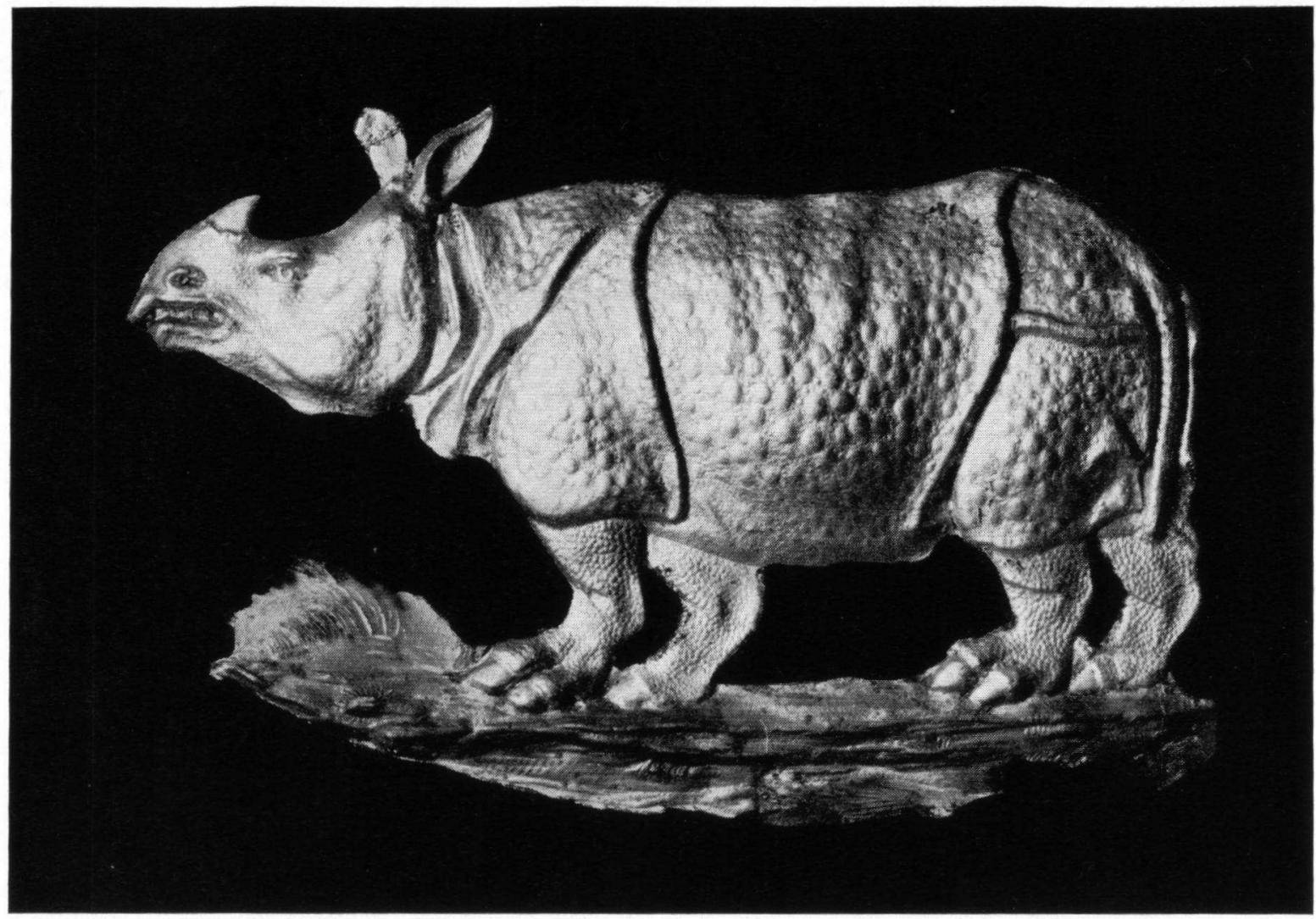

Fig. 9. The clay model made by Petrus Camper in Leiden, possibly in 1748 (size $19 \times 14 \mathrm{~cm}$ ), kept in the Rijksmuseum van Natuurlijke Historie, Leiden (specimen no. VI). (Photo: Rijksmuseum van Natuurlijke Historie, Leiden).

"'le gros rhinocéros que nous avons vu l'hiver dernier" (according to Loisel, 1912, II: 278)

("the great rhinoceros we have seen during the last winter").

Loisel (loc.cit.) concludes from this that the animal must already have been in Paris in 1748. However, considering the fact that it left Reims on the 30th of December, 1748 and after this visited Versailles, it seems more probable that it did not arrive in Paris until the beginning of 1749; an opinion which all other writers confirm. In Paris the animal was painted by Jean Baptiste Oudry (1686-1755). This rather large painting $(310 \times 456$ $\mathrm{cm})$ was Iater sold to the duke of Schwerin; it is now in the possession of the Staatliches Museum in Schwerin, Germany (inv. no. 807). Etienne Charpentier (1705- (still alive) 1764) made an engraving entitled

"véritable portrait d'un rhinocéros vivant que l'on voit à la foire St. Germain à Paris" (Buf- fon, 1754: 180-181),

("a true representation of a living rhinoceros to be seen at the fair of St. Germain in $\mathrm{Pa}$ ris").

Buffon, too, (1754, pl. VII) ordered a representation to be made of it in Paris (fig. 10).

The animal left Paris for Lyon on a date unknown to me. On November 21, 1749 D'Argenson reported (according to Loisel, 1912, II: 280) that the animal had died. He reported that a ship that brought it from Rome to Naples had shipwrecked and that the rhinoceros, its keepers and the other passengers had all drowned. Loisel (loc.cit.) thinks it likely - rightly, in my opinion that

"c'était là encore une fausse nouvelle, car le rhinocéros que nous avons vu au carnival de Venise en 1751, parait bien être la même bête" ("this was a false report, as the rhinoceros that we have seen at the carnaval in Venice in 1751 seems to be the same animal"). 


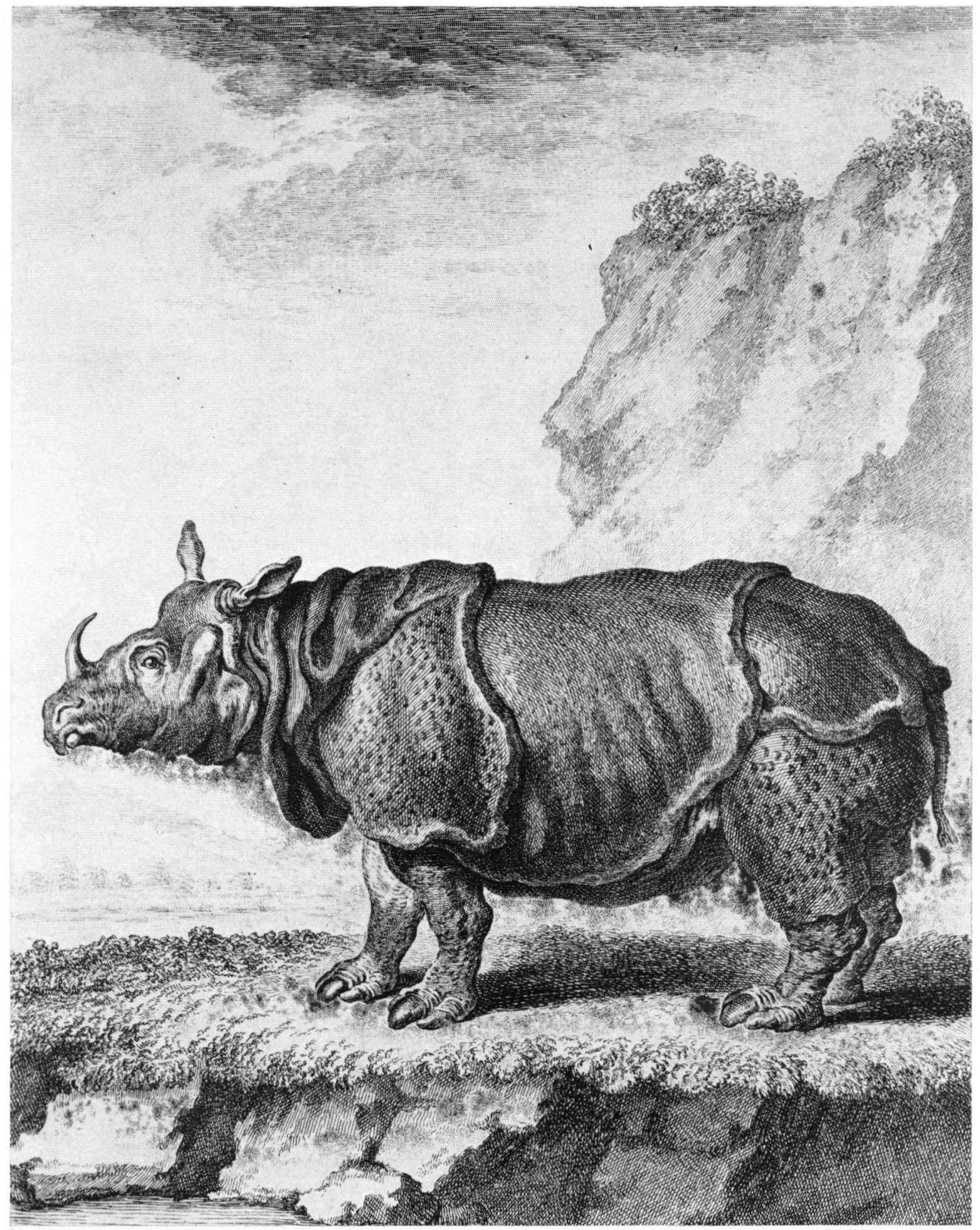

Fig. 10. Buffon's (1754, pl. 7) representation of the rhinoceros in Paris, 1749 (specimen no. VI). (Photo: Artislibrary, Amsterdam). 


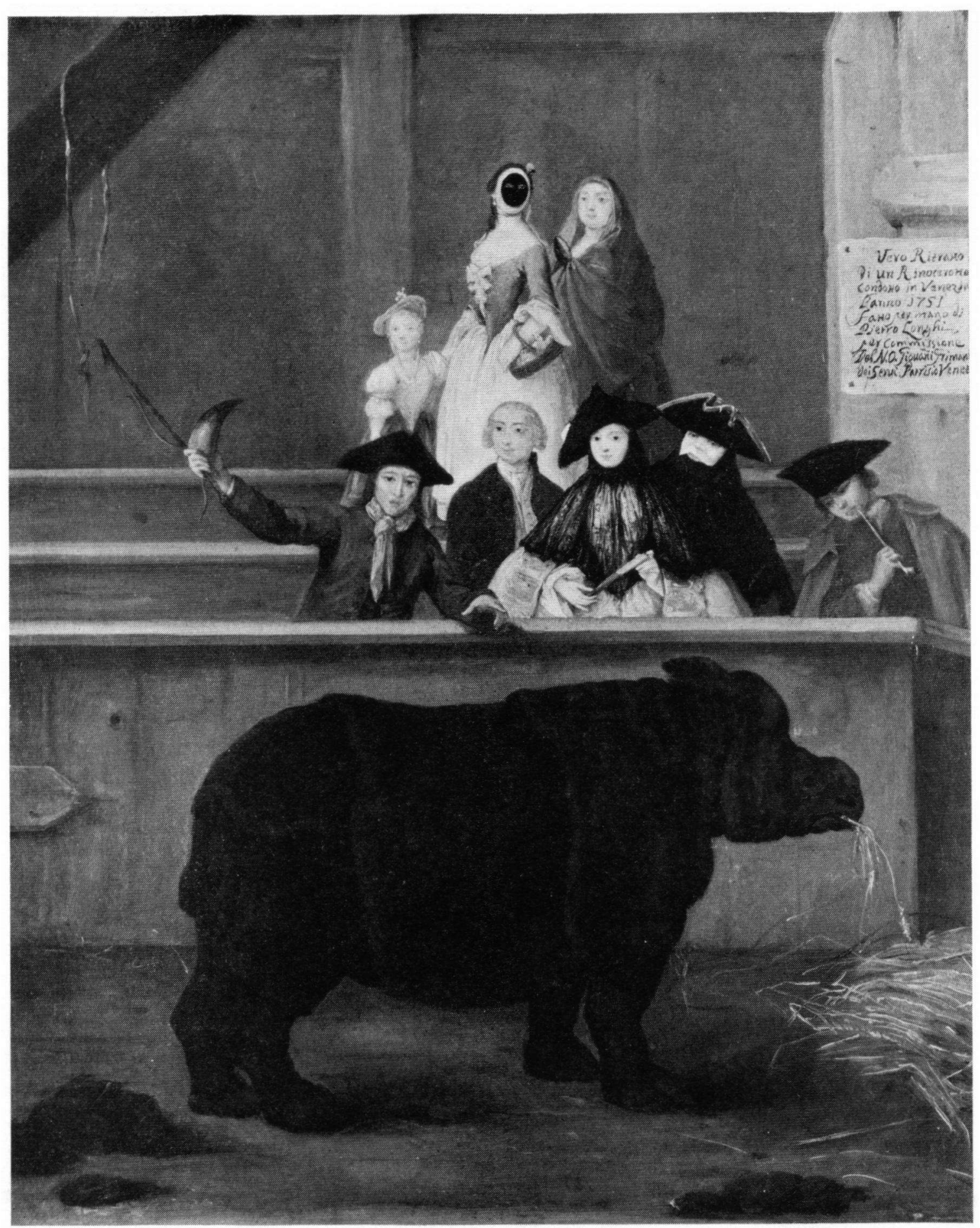

Fig. 11. The Ca'Rezzonico version of the painting "Il rinoceronte" by Pietro Longhi, 1751. Notice the poster in the background on the right (specimen no. VI). (Photo: Toso, Venice). 
From 1750 till 1751 the animal was in Vienna, Austria, as appears from the following information provided by L. J. Fitzinger:

"Das von $1741 \ldots$ war ein Weibchen, wurde von einem Hollander gebracht und 1749 in Paris und 1750 und 1751 auch in Wien gezeigt" (according to Giese, 1962: 138),

("The one of $1741 \ldots$ was a female, was brought to Paris in 1749 by a Dutchman and also shown in Vienna from 1750 till 1751"). When it entered Vienna it was welcomed by a guard of honour of Kurassiers (Guggisberg, 1966: 128).

The next place we meet the animal is Venice, Italy (cf. a.o. Loisel, 1912, II: 11). In this town it was painted by Pietro Longhi (1702-1785; this in contrast to the dates given by Mohr, 1957: 42 and Petzsch, 1961: 110). Different versions of this painting exist, all dating from 1751. One of these (size: $62 \times 50 \mathrm{~cm}$ ) is to be found in the $\mathrm{Ca}$ 'Rezzonico collection in Venice (inv. no. 1312) (fig. 11) and the other (size: $60,4 \times 47 \mathrm{~cm}$ ) in the National Gallery in London (inv. no. 1101) (Levey, 1956: $72-73$ and Pignatti, 1968: 89, 100). The two versions are not exactly alike; their differences have been described by Levey (1956: 72). The most important feature of the Ca'Rezzonico version is the poster in the background to the right, which is missing in the National Gallery version. It reads:
"Vero Ritratto di un rinocerotto, condotto in Venezia l'anno 1751, fatto per mano di Pietro Longhi per commissione del N.O. Giovanni Grimani dei Servi, Patrizio Veneto" (Pignatti, 1968: 100),

("A true representation of the rhinoceros that was brought to Venice in 1751, painted by Pietro Longhi on commission of the nobleman Giovanni Grimani dei Servi, Venetian patrician").

Several other versions of this painting and also an engraving exist, all made either by Pietro Longhi or by his son Alessandro Longhi. More information concerning this can be found in Levey (1956: 73-74).

After Venice the animal was exhibited in the amphitheatre of Verona, Italy. Guggisberg (1966: 129) writes that it in Verona

"had the distinction of featuring on a medal struck to celebrate the occasion".

On December 5, 1751 a daughter (called Elisabeth) of Douwe Mout van der Meer was baptized in the Pieterskerk in Leiden (W. Downer, in litt., August 19, 1971). It is not certain whether Douwe Mout was present at the ceremony, nor is it known where the rhinoceros was at that time. But it is not impossible that Douwe Mout as well as the rhinoceros were in Leiden at the end of 1751 .

Its further life history is rather uncertain. In 1752 there was a female Indian rhinoceros in London,

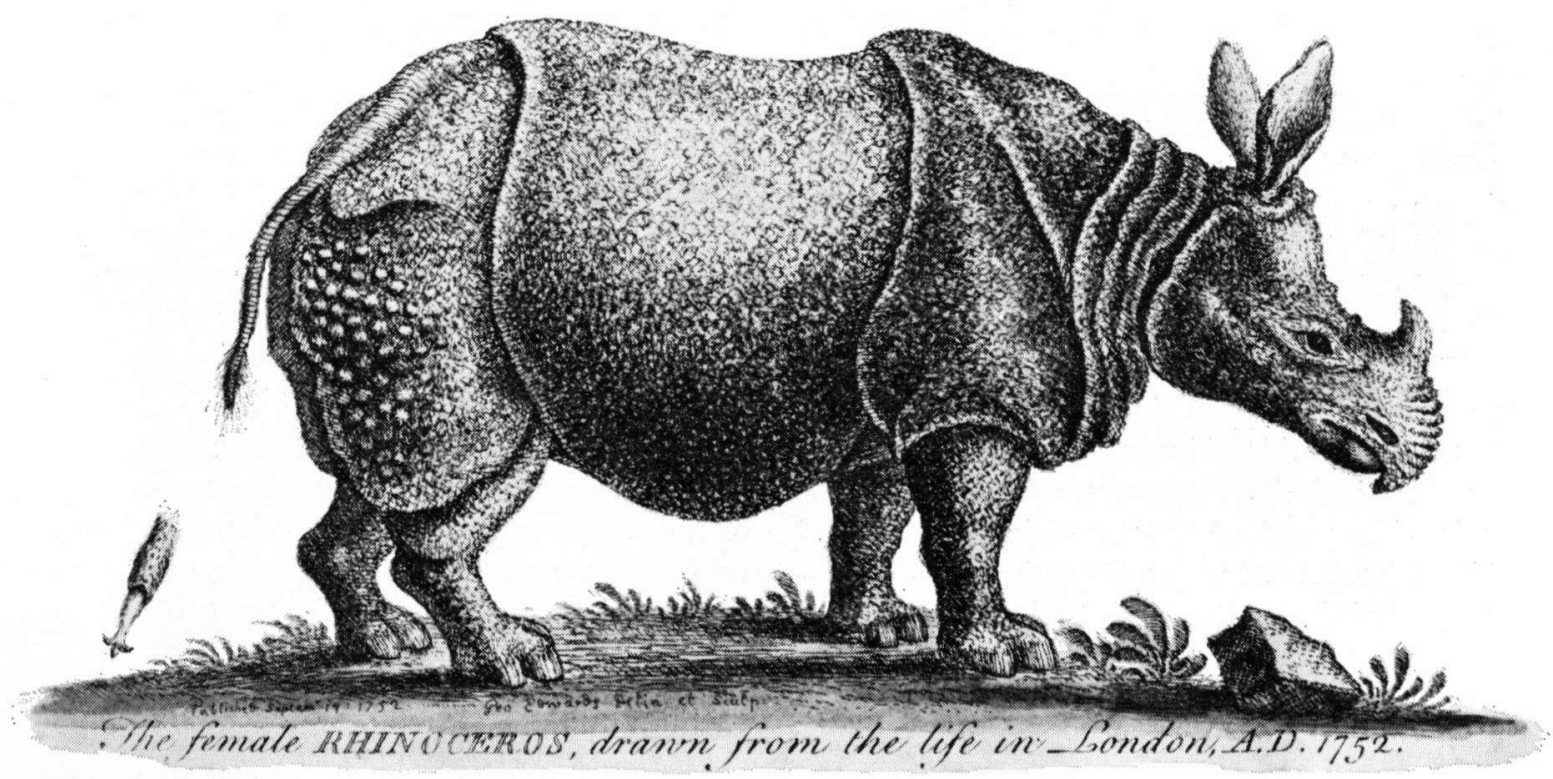

Fig. 12. Edwards' (1758, fig. 221) representation of the rhinoceros in London in 1752 (specimen no. VI). (Photo: Artis-library, Amsterdam). 
of which George Edwards (1758: 24 and fig. 221) published a picture (fig. 12). Buffon (1754: 175) remarks about this animal that

"c'est le même Rhinocéros femelle que nous avons vû et fait dessiner à Paris en 1749" (Buffon, loc. cit.)

("it is the same female rhinoceros we have seen in Paris in 1749").

This is probably true, though Edwards (loc. cit.) says that the animal is not yet fully grown. However, he does not say on what data he bases this remark.

In 1784 Johannes le Franq van Berkhey (1729. 1812) published a catalogue of his collection of etchings, drawings etc., in which he mentions the following drawing (?):

"Rhinoceros accurate \& ad vivum delineavit. J. le Fr. v. Berkhey, $A^{\circ}$. 1758. De Rhinaster die $A^{\circ} .1758$ in dit land [= Nederland] te zien is geweest, accuraat naar 't leven getekend, door J. le Fr. v. Berkhey" (Berkhey, 1784: 48),

("Rhinoceros that has been shown in this country [ $=$ Holland] in the year 1758 , drawn from life by J. le Fr. v. Berkhey").

I have not been able to find this drawing. It is possible that the above described animal is meant, because I do not think it at all unlikely that Douwe Mout van der Meer remained in Holland after his long trip. There are no proofs of this, however. The subsequent life history or the date of death of the rhinoceros are not known to me.

Apart from the above mentioned paintings, woodcuts, etchings, poster and medals there is also a picture of this rhinoceros on the 'Fayenne-Tintengeschirr' of Gottfried Keller (1819-1890), that is kept in the Central Library of Zürich (Coste, 1946: 127). Besides, the animal inspired Christian Fürchtegott Gellert (1715-1769) to writing his fable "Der arme Greis" in Berlin.

The food of this rhinoceros consisted of hay, straw, bread, fruits and vegetables. It ate 60 pounds of hay and 20 pounds of bread daily and drank 14 buckets of water. Sometimes it was given wine and beer. It seems to have been fond of the smell of tobacco and now and then the ones who took care of it blew smoke into his nostrils and mouth (Ladvocat, 1749: 10).

In 1741 it weighed 3000 pounds (Noll, 1873), but in Berlin (1746) it weighed not less than 5000 pounds (Klös, 1969: 17); two years later in Stutt- gart its weight was still the same (Petzsch, 1954: 52). Bicker Raye mentions the fact that the animal was 5 feet $(=152 \mathrm{~cm})$ high in 1741 (Beyerinck \& de Boer, 1935: 91), while in Augsburg in 1748 its height is said to be $51 / 2$ feet $(=165 \mathrm{~cm})$ (Ridinger, 1768: pl. 53). Ridinger (loc. cit.) adds that the animal was $11 \frac{1}{2}$ feet $(=348 \mathrm{~cm})$ long. On the etchings in the Rijksprentenkabinet in Amsterdam is written that in May 1747 it was

"5 voet en 7 duym [ $=170 \mathrm{~cm}]$ hoog en 12 voet $[=365 \mathrm{~cm}]$ dick",

("5 feet and 7 inches $[=170 \mathrm{~cm}]$ high and 12 feet [ $=365 \mathrm{~cm}]$ thick").

To the above quoted measurements no information is added, however, as to how the animal was measured. In Paris (1749) it was measured by Ladvocat. He writes about this and the above quoted measurements:

"Tout cela n'est dit que pour exciter la curiosité des spectateurs. Car je l'ai mesuré, il a dix pieds $[=304 \mathrm{~cm}]$ de longueur depuis les oreilles jusqu'au fondement et dix pieds de circonférence en le mesurant par le milieu du corps. Sa hauteur est de cinq pieds quatre pouces [ $=162 \mathrm{~cm}$ ] ou environ" (Ladvocat, 1749: 7).

("All these measurements were only given to excite the curiosity of the spectators. For I have measured it; it was 10 feet $[=304 \mathrm{~cm}]$ long from the ears to the root of the tail and 10 feet in circumference measured in the middle of its body. Its height is about 5 feet 4 inches [ $=162 \mathrm{~cm}$ ]').

About the length of the horn the following can be said. The animal is depicted on the Leipzigposter (1747), in Augsburg (1748) (Ridinger, 1768, pl. 53) and in Paris (1749) (Buffon, 1754, pl. VII) having a rather long horn. From Paris stems the information that the horn was 9 inches $(=22 \mathrm{~cm})$ long measured from its base when the animal was there (Ladvocat, 1749: 13).

In Venice the animal has only a very small horn. Petzsch (1961: 111) discusses the possible cause of this and comes to the conclusion that it cannot be traced whether the animal has slowly scoured the horn down or whether it broke off on some occasion or other. We are told by Barth (1747:3), however, that the rhinoceros often scoured off its not very long horn. Camper (1782: 148) gives the same information about the animal that was in Leiden in 1748 . On the representation made by Edwards (1758, fig. 221) in London in 1752 (fig. 12), 
the horn is somewhat larger, so that it seems that since Venice the horn has grown somewhat.

\section{VII}

The animal now to be discussed lived at the end of the 18th century in the menagerie of Versailles. It is not certain to what species it belonged. Loisel (1912) says that the menagerie of Versailles

"reçut un rhinocéros bicorne que M. Bertin, ministre d'Etat, avait fait venir du Cap" (Loisel, 1912, II:143),

("received a two-horned rhinoceros that $\mathrm{Mr}$. Bertin, minister of state, had ordered from the Cape" [of Good Hope]).

This leads to the conclusion that it must have been a Diceros bicornis. Objections can be raised against this, however. Prof. Sanders (1779: 5) mentions not only that the animal came from Bengal, but he mentions only one horn. After the death of the rhinoceros its skeleton was sent to the "Muséum d'Histoire Naturelle" in Paris, where Cuvier (1804) described it as a rhinoceros with one horn. Therefore it seems most likely that this animal belonged to the Indian species (Rhinoceros unicornis) and was brought from Bengal, with perhaps a stop at the Cape of Good Hope, to France.

Although Reynolds (1960: 23) mentions 1779 as the date of arrival, it is rather certain that this male animal arrived in Versailles some years before that. Lacépède (1818: 244) mentions September 1770, whereas Schreber (1835: 297) mentions 1771. Prof. Sanders (1779) writes in 1779:

"Das Nashorn ist bereits 10 Jahre alt, kam im zweiten Jahr hieher" etc. (Sanders, op. cit.: 2),

('The rhinoceros is already 10 years old, it came to France in its second year" etc.).

So in 1779 it was already eight years in Europe, that means that it arrived in 1771. A more precise date is not known.

On its arrival the animal was two years old and was kept in Versailles in an enclosure that was $19,5 \mathrm{~m}$ broad and $23,4 \mathrm{~m}$ long. It was connected to a small stable and was provided with a water basin where it could drink (Loisel, 1912, II: 144). When it grew older, the animal hid itself in this completely, except for its ears and nose (Camper, 1782: 147). It was fed daily with 200 pounds of food, consisting of hay, grass, oats and flour (Sanders, 1779: 2).

Little is known about its life. It was one of the five animals that were still alive in Versailles after the French Revolution in 1789. The other animals that were still alive were among other a lion from Senegal and a quagga from the Cape of Good Hope (Hamy, 1893: 9). The rhinoceros drowned in its basin in July 1793 (Lacépède et al., 1817: 131) and its skeleton was afterwards transported to Paris. Reynolds (1960: 23) says, that the animal was transported with the whole menagerie of Versailles to the Jardin des Plantes in Paris in 1794, but this is incorrect. Reynolds makes this mistake by positing too late a date of arrival.

\section{VIII}

The next three rhinoceroses were all shown in the Exeter Change Menagerie in London, about which Loisel (1912) says the following:

"Un commerçant d'animaux sauvages, Pidcok, forma un dépôt de bêtes rares à Exeter Change, dans le Strand (à l'est de Burleigh Street). ..La ménagerie d'Exeter passa ensuite dans les mains d'un certain Cross et finalement fut vendue" (Loisel, 1912, II: 17),

("A trader in wild animals, Pidcok, established a depot for rare animals in Exeter Change, on the Strand (east of Burleigh Street). ..The menagerie then came in the possession of a Mr. Cross and was sold in the end").

The first of these three animals probably arrived in 1770 (Loisel, loc. cit.). It was painted by George Stubbs (1724-1806) in 1772. From this painting appears clearly that it is an Indian rhinoceros (Rhinoceros unicornis). John Hunter bought the painting for his scientific museum (Taylor, 1971: 210, figs. 71 and 72). No other writer mentions this animal.

\section{IX}

In 1790 Pidcok seems to have exhibited another Indian rhinoceros (Rhinoceros unicornis) (Guggisberg, 1966: 129). Again, little is known of this animal. Nine months before its death it dislocated its right fore leg and the subsequent inflammation led to its death (Jardine, 1843: 171). The only other fact known to me is that it was fond of wine, of which it sometimes drank three or four bottles in a few hours (Guggisberg, 1966: 129). 


\section{$\mathrm{X}$}

In 1799 Pidcok received another Rhinoceros unicornis. This animal was sold for $£ 1000$ to an agent of the Emperor of Germany (Jardine, 1843: 171). It remained in London, however, awaiting a suitable occasion to send it to Vienna (Thomas, 1801: 145). It was intended for the imperial menagerie in Vienna (Schreber, 1835: 298).

On its arrival the animal was still very young (Lacépède et al., 1817: 116). Its food consisted of hay, oats, potatoes and vegetables. On this diet it remained completely healthy until it got respiratory troubles a few days before its death. The cause of death is said to be that

"the lungs every where adhered to the inside of the thorax, and were in a high state of inflammation" (Thomas, 1801: 149).

It died shortly after its arrival in London, thus before it could be shipped to Vienna. A dissection of this male animal was carried out by $\mathbf{H}$. Leigh Thomas (1801).

\section{XI}

During an expedition to gather animals made by the Schönbrunn zoological garden in Vienna, among others a living rhinoceros was captured. The expedition was led by Franz Boos and Georg Scholl. On February 5, 1788 Boos left the Cape of Good Hope with a great number of the acquired animals and plants. Scholl remained and, owing to political changes - among which the French Revolution - was to follow only 13 years later, that is in 1801 (Fitzinger, 1836). The very young rhinoceros that belonged to the Javan species (Rhinoceros sondaicus Desmarest, 1822) died on its way to Hamburg, Germany. The animal was stuffed and brought to Vienna where it is kept in the Kaiserlich Museum (Antonius, 1937: 24 and fig. 6).

\section{XII}

In the Exeter Change Menagerie in London another Indian rhinoceros (Rhinoceros unicornis) arrived in 1810. It was a male animal, which on its arrival probably was very young, since in $\mathrm{Pa}$ ris, in 1815, it is still said to be young (GeoffroySaint Hilaire and Cuvier, 1820). It was shown in London for only four years (Guggisberg, 1966: 129), because it was shipped in 1814 to the menagerie in Stuttgart. Owing to the sudden death of the king, it never arrived there, but was bought by Tourniaire (Schreber, 1835: 298). While the animal was still in London, at least two drawings of it were made by Thomas Landseer (17951880); one of these was published by Edward Griffith (1827, III, opposite p. 425). W. Kourist (1970) writes about the other drawing of Landseer:

"Ebenfalls in dem von Thomas Landseer (1795-1880) illustrierten Prachtwerk von John Henry Barrow aus dem Jahre 1832 ['Characteristic sketches of animals principally in the Zoological Gardens, Regent's Park. London.'] findet sich dieses Nashorn noch auf einem der dort publizierten Kupferstiche wieder (Abb. 5)" (Kourist, 1970: 145),

("Also in the very fine book of John Henry Barrow from 1832 ['Characteristic sketches of animals principally in the Zoological Gardens, Regent's Park. London.'], illustrated by Thomas Landseer, this rhinoceros is represented in one of its copper-plates (fig. 5)."). Kourist also gives a representation of this drawing (op. cit., fig. 5). However, Landseer did not make these two drawings in the Jardin des Plantes, Paris in 1832 (Kourist, loc. cit.), but in 1814 in London, as Griffith (1827: 424) as well as Schreber (1835: 298) tell us. Moreover, Kourist writes:

"Noch in London fertigte Moses Griffith (1749-1809) eine gute Abbilding an" (Kourist, 1970: 145),

("In London Moses Griffith (1749-1809) made a good representation").

Unfortunately I could find no information about this representation elsewhere; it seems unlikely, however, that a rhinoceros that landed in England in 1810, was drawn by a man who died in 1809 .

In 1815 it was shown for three months in Paris (Anonymous, 1819: 240). Here it was represented by James Forbes as a detail of a sepia drawing on occasion of his visit to Paris (Kourist, 1970: 145, cf. also his fig. 4). Besides, two lithographs were made of it there and published in January 1820 by Geoffroy-Saint Hilaire \& $\mathrm{Cu}$ vier (1820). One of these is reproduced here (fig. 13). The rhinoceros was said to be of the following size:

"Sa hauteur, à la partie la plus élevée de son dos, était 4 pieds 10 pouces $[=147 \mathrm{~cm}]$, et sa longueur du derrière à l'extrémité de la tête, était de 7 pieds [ $=213 \mathrm{~cm}$ ]." (Geoffroy-St. Hilaire \& Cuvier, 1820),

("Its height, on the highest part of its back, was 4 feet 10 inches $[=147 \mathrm{~cm}]$ and its length 


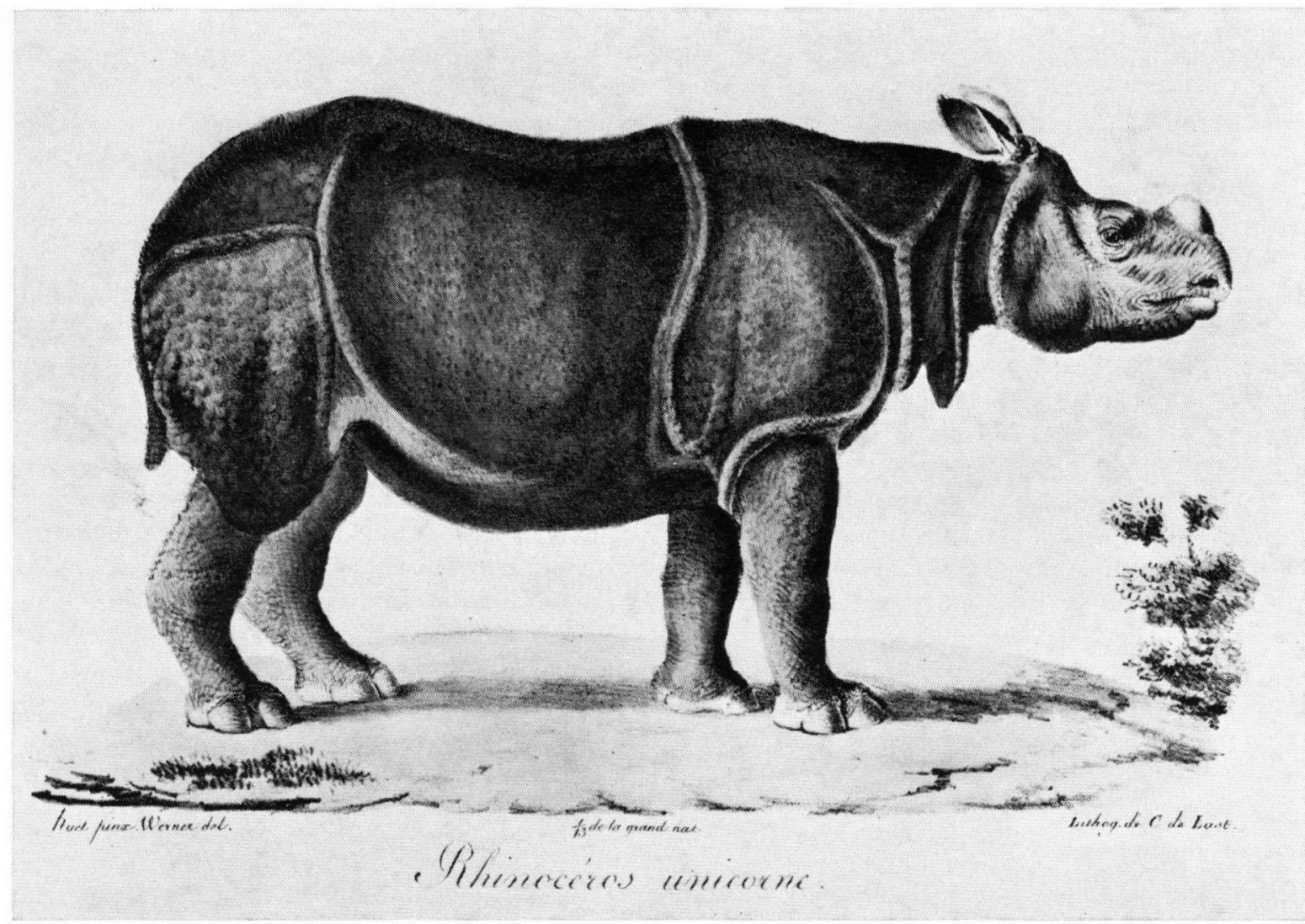

Fig. 13. The rhinoceros in Paris in 1815, published in 1820 by Geoffroy-St. Hilaire \& Cuvier (specimen no. XII). (Photo: Artis-library, Amsterdam).

from its rump to the extremity of its head was 7 feet [ $=213 \mathrm{~cm}]$ ").

Reynolds (1960: 21) tells us without further information that according to Hans Kuhn, a rhinoceros was shown in the then menagerie in Frankfurt am Main (Germany) in 1816. This animal then went to Neurenberg, where a representation of it was published by Johann Wolf $(1818$, pl. XIX). This plate was

"nach dem Leben gezeichnet von A. Gabler", ("drawn after life by A. Gabler").

The rhinoceros has on this drawing a rather well developed horn.

In 1819 it was exhibited on the 'Ostermesse', also called 'Jubilatemesse', that lasted from April 22 to 30, 1819 in Leipzig (Stadtarchiv Leipzig. in litt., April 17, 1972). Also, Engelmann (1846: 362) mentions the following booklet: "Das Rhinozeros oder Nashorn auf der Leipziger Ostermesse 1819."" (also under the title): "Vorzuig- liche Merkwürdigkeiten auf den Leipziger Messen. 1 Hft. Mit Kpfr. gr. 8 Leipzig 1819"'. About its stay nothing else is known to me and also about the subsequent years of its life no information could be found.

Only in 1833 we find it again in Paris (Schreber, 1835: 299). From there it went to Germany where D. J. Wagner saw it at the summer fair in München in 1835 (Schreber, loc. cit.). Then it went to Vienna, still accompanied by Tourniaire. It remained there a few weeks, after which it departed for an unknown destination (Giese, 1962: 138-139). I have no information about the date and place of death.

Two remarks follow below, which could not be included in the preceding chronological list, as they cannot be dated accurately. Whether the information given below is true, I cannot substantiate at this moment. 


\section{XIII}

The first report comes from Samuel Gmelin (1767), who writes that he saw a rhinoceros that came from Africa. He adds to this that the animal

"bijna anderhalf jaar oud was, welke in Europa aankomende, geen hoornen had, en eenigen tijd daarnaa den voorsten kreeg" (Gmelin, 1767: 634),

("was almost one year and a half old, and when it arrived in Europe, it had no horns but some time later it grew the front one"). In spite of this, it is not at all certain that the animal really came from Africa. It could have been an Asiatic rhinoceros that was brought to Europe via Africa. As Gmelin thought that there existed only one species of rhinoceros, that in its younger years only has one horn, later two and sometimes when very old gets a third one, it is not at all unlikely that the anterior horn Gmelin mentions, was really the only one. Consequently, it is impossible to tell to which species this animal belonged.

\section{XIV}

A very interesting remark is made by J. D. Pasteur (1793), namely:

"Voor enige jaaren zou men met eenen, die twee hoornen hadt, bij Manheim over den Rhijn vaaren, maar de schuit, waarin hij was, gong te gronde en het dier verdronk"(Pasteur, 1793: 141),

("Some years ago one would cross the Rhine near Mannheim with one with two horns, but the boat in which it was, shipwrecked and the animal died").

One cannot be sure which species of two-horned rhinoceros is meant here, but as neither the square-lipped rhinoceros (Ceratotherium simum (Burchell, 1817)) nor the Sumatran rhinoceros (Dicerorhinus sumatrensis (G. Fischer, 1814)) had yet been described, and therefore probably would have caused quite a stir among the experts, it seems likely that it was a black rhinoceros (Diceros bicornis). Further details are unknown to me.

\section{ACKNOWLEDGEMENTS}

I am particularly grateful to Mrs. Drs. F. PeetersPieters, librarian of the Artis library, Amsterdam, for her continuous encouragement, advice and assistance. I thank Drs. P. J. H. van Bree of the Zoölogisch Museum, University of Amsterdam, for reviewing the manuscript and for his useful comments. I also acknowledge the very useful help of M. D. Haga, of the Rijksprentenkabinet, Rijksmuseum, Amsterdam; Prof. Dr. H. Hediger, Zürich; Dr. D. A. Hooyer, of the Rijksmuseum van Natuurlijke Historie, Leiden; Mrs. H. M. van der Meulen-Schregardus, Yorktown Heights, U.S.A., and Prof. Dr. H. Petzsch, Halle/Saale.

Thanks are extended to the following archives and libraries that provided me with valuable information and assisted me in my search for the often rare literature: Gemcentelijke Archiefdienst, Leiden (archivist mr. W.
Downer); the Staatsarchiv in Dresden, D.D.R.; the Stadtarchiv of Leipzig; the libraries of the University of Leiden, the University of Amsterdam, and the British Museum (Natural History), London; the Bibliotheque Nationale, Paris and the Hessische Landes- und Hochschulbibliothek in Darmstadt, Germany. I acknowledge the kind assistance of the musea that consented to the publication of photographs of the works in their care: the Graphische Sammlung Albertina, Vienna; the National Gallery, London; the British Museum, London; the Rijksmuseum, Amsterdam; the Rijksmuseum van Natuurlijke Historie, Leiden and the Ca'Rezzonico collection in Venice.

Finally I like to thank my brother, H. R. Rookmaaker, who greatly helped me by translating the Dutch manuscript into English.

\section{BIBLIOGRAPHY}

Albinus, B. S., 1747. Tabulae sceleti et musculorum corporis humani. (apud Johannem et Hermannum Verbeek, Lugduni Batavorum).

ANONYMOUS, 1819. Nouveau dictionnaire d'histoire naturelle, appliquée aux arts, à l'agriculture, à l'économie rurale domestique, à la médicine etc. par une société de naturalistes et d'agriculteurs. Nouvelle édition, 29 : i-iv, 1-576. (Deterville, Paris).

ANONYMOUS, 1855. Le rhinocéros du roi Emmanuel. Son triomphe et sa mort. Magasin pittoresque, 23 : 202203.

ANTONIUS, O., 1937. Bilder aus dem früheren und jetzigen Schönbrunner Tierbestand. I. Nashörner. Zool. Gart. Lpz., (N.F.) 9 (1/2) : 18-26, figs. 1-7.

BARTH, J. M., 1747. Schreiben an einen guten Freund, darinne von einem vor wenig Wochen hieher gebrachten Rhinocerote oder Nashorn umständliche Nachricht gegeben, und zugleich untersucht wird: ob dieses 
Thier der Hiob Cap. XL. v. 10. seqq. beschriebene Behemoth: ( $1-8$, unnumbered). (bey Zunkels Gebrüdern, Regensburg).

BERGEN, C. A. $\lambda, 1746$. Oratio de rhinocerote, quam habuit XVI. Octob. MDCCXLVI quum tertium poneret rectoratum academiae: (1-31, unnumbered). (apud Ioh. Christian. Kleyb, Francofurti ad Viadrum).

BerKHeY, J. LE FranQ VAN, 1784. Eerste catalogus van de uitgebreide systhematische natuurkundige verzameling van teekeningen, printen en afgezette afbeeldingen, van allerleye classen van dieren en planten, alle naar eene systhematische rang, zindelyk op een en 't zelve atlasformaat gebragt, en in ruim 160 byzonder zoort portefeuilles en omslagen in den tijd van bijnaar veertig jaren bijeenverzamelt, bereid en zindlijk verzamelt: 1, i-viii, 1-200. (Theodorus Crayenschot, Amsterdam).

BEYERINCK, F. \& M. G. DE BOER, 1935. Jacob Bicker Raye "Notitie van het merkwaardigste meyn bekent" 1732-1772, naar het oorspronkelijk dagboek medegedeeld: i-xii, 1-383. (N.V. Uitgevers-Maatschappij „Joost van den Vondel", Amsterdam).

Broun, W. H., 1905. Exhibition of mounted heads of a white waterbuck and two rhinoceroses. Proc. zool. Soc. Lond., 1905 (2) : 296-297.

BufFon, [G.-L. LeCLeRC] DE \& [L. J.-M.] DAubENTON, 1754. Histoire naturelie, générale et particuliére, avec la description du Cabinet du Roi, 11: i-iv, 1-451, pls. I-XLIII. (Imprimerie Royale, Paris).

Camerarius, J., 1595. Symbolorum et emblematum ex animalibus quadrupedibus desumtorum centuria altera collecta a Ioachimo Camerario medico Norimberg. Exponuntur in hoc libro rariores tum animalium proprietes tum historiae ac sententiae memorabiles: 1-116, pls. 1-100. (P. Kaufmann, Noribergae).

Camper, P., 1782. Natuurkundige verhandelingen van Petrus Camper over den Orang Outang; en eenige andere aapsoorten. Over den Rhinoceros met den dubbelen horen; en over het rendier: $1-4,1-235$, $1-2$, pls. $1-5,1-3,1$. (De erven $P$. Meyer en $G$. Warnars, Amsterdam).

Carus, J. V. \& W. Engelmann, 1861. Bibliotheca zoologica. Verzeichniss der Schriften über Zoologie, welche in den periodischen Werken enthalten und vom Jahre 1846-1860 selbständig erschienen sind. Mit Einschluss der allgemein-naturgeschichtlichen, periodischen und palaeontologischen Schriften, 1: i-xxiv, 1-950, 2 : i-iv, 951-2144. (W. Engelmann, Leipzig).

Cole, F. J., 1953. The history of Albrecht Dürer's rhinoceros in zoological literature. Sci. Med. Hist., 1: 337356 , figs. $1-22$.

Coste, C., 1946. Anciennes figurations du Rhinocéros de l'Inde. A propos du frontispiece de l'ouvrage de Wilhelm Pison "De Indiae utriusque re naturali et medica", édité à Amsterdam en 1658. Acta Tropica, 3 (2) : $116-129$, figs. $1-12$.

Cuvier, [G. L. C. F. D.], 1804. Description ostéologique du rhinocéros unicorne. Annls Mus. Hist. nat. Paris, 3 : 32-52, pls. 3-5.

DA Costa, A. Fontoura, 1937. Deambulations of the rhinoceros (Ganda) of Muzafar, king of Cambaia, from 1514 to $1516: 1-53$, figs. $1-6$. (Lisboa).

Dodgson, C., 1903. Catalogue of early German and Flemish woodcuts preserved in the department of prints and drawings in the British Museum, 1: i-xii, 1-568. (British Museum, London).

-, 1938. The story of Dürer's Ganda. In: FowLER, A., The romance of fine prints: $44-56$, pls. $1-3$. (The Print Society, Kansas City).

EDWARDS, G., 1758. Gleanings of natural history, exhibiting figures of quadrupeds, birds, insects, plants \& c., most of which have not, till now, been either figured or described, with descriptions of seventy different subjects, designed, engraved and coloured after nature, on fifty copper-plate prints, 1: i-viii, 1-108, pls. 211-260. (Royal College of Physicians, London).

ENGELMANN, W., 1846. Bibliotheca historico-naturalis. Verzeichniss der Bücher über Naturgeschichte welche in Deutschland, Scandinavien, Holland, England, Frankreich, Italien und Spanien in den Jahren 17001846 erschienen sind, 1: i-ix, 1-786. (W. Engelmann, Leipzig).

EVELYN, J., 1908. The diary of John Evelyn (1620 to 1706), with an introduction and notes by Austin Dobson: i-xl, 1-540. (McMillan, London).

FAENSEN, H., 1963. Albrecht Dürer schriftlicher Nachlass, eine Auswahl, ed. 2: 1-288, figs. 1-106. (Union Verlag, Berlin).

FITZINGER, L. J., 1836. Tourniaire's Menagerie. Wiener Zeitschrift, 16. Juni 1836. (according to GIESE, 1962).

FrEYTAG, F. G., 1747. Rhinoceros e veterum scriptorum monumentis descriptus: $\mathrm{i}-\mathrm{ii}, 1-38$. (ex officina Langenhemiana, Lipsiae).

GeE, E. P., 1952. Early rhinoceros in Europe. Ctry Life, 112 : 401, fig. 1.

Geoffroy-Saint Hilaire, [E.] \& F.[-G.] Cuvier, 1820. Le rhinocéros unicorne male. In: - \& -, 1818-1842. Histoire naturelle des mammifères, avec figures originales, coloriées, dessinées, d'après des animaux vivants, 6 [13] : 1-3, pls. 1-2. (Blaise, Paris).

GiesE, U., 1962. Wiener Menagerien. Ebersdorf, Neugebäude, Belvedere, Schönbrunn. Osterreich-Reihe 165/ $167: 1-168$, pis. $1-30$, figs. $1-13$. (Bergland Verlag, Wien).

GmeliN, S., 1767. Waarneeming over den Rhinoceros of Neushoorn. Verh. holland. Maatsch. Wet., 9 (3) : 632-636.

Gowers, W., 1952. Early rhinoceros in Europe. Ctry Life, 111: $288-289$, figs. $1-4$.

Griffith, E., 1827. The animal kingdom arranged in conformity with its organization by the Baron Cuvier, with additional descriptions of all the species hitherto named, and of many not before noticed, $3: \mathrm{i}-\mathrm{-vi}$, 1-468. (Geo. B. Whittaker, London).

GugGisberG, C. A. W., 1966. S.O.S. Rhino: 1-174, pls. 1-8, figs. 1-6. (André Deutsch, London).

HAMY, E.-T., 1893. Les anciennes ménageries royales et la ménagerie nationale, fondée le 14 Brumaire an II (4 nov. 1793). Nouv. Archs. Mus. Hist. nat. Paris, (3) $5: 1-15$.

Hausmann, B., 1922. Albrecht Dürer's Kupferstiche, Radirungen, Holzschnitte und Zeichnungen, unter besonderer Berücksichtigung der dazu verwandten Papiere und deren Wasserzeichen: 1, i-iii, 1-130. (J. Frank's Buchhandlung, Würzburg).

Hediger, H., 1970. Ein Nashorn mit Dürer-Hornlein. Zool. Gart. Lpz., (N.F.) 39 (1/6): 101-106, figs. 1-6. 
JARDINE, W., 1843. Thick skinned quadrupeds. In: The Naturalists Library. Mammalia, 9: i-xvi, 1-248. (W. H. Lizards, Edinburgh).

KLös, H.-G., 1969. Von der Menagerie zum Tierparadis. 125 Jahre Zoo Berlin: 1-320. (Haude \& Spener, Berlin).

KLöS, H.-G. \& H. FRäDRICH, 1970. Ein Überblick über die in Zoologischen Gärten gehaltenen afrikanischen Nashörner. Zool. Gart. Lpz., (N.F.) 38 (5): 227-245, figs. $1-5$, tabs. $1-2$.

- \& -, 1971. Veränderungen im Bestand afrikanischer Nashörner in Zoologischen Gärten. Zool. Gart. Lpz., (N.F.) 41 (1/2): 49-55, tabs. 1-2.

KourIST, W., 1970. Die ersten einhörnigen Nashörner (Rhinoceros sondaicus Desmarest, 1822 und Rhinoceros unicornis L., 1758) der grossen europäischen Zoologischen Gärten in der Malerei des 19. Jahrhunderts. Zool. Beitr., (N.F.) 16 (1): 141-154, figs. $1-13$.

LACÉPÈde, [B. G. E. DE la Ville], 1818. Oeuvres complètes de Buffon, mises en ordre, précédées d'une notice sur la vie de l'auteur et suivies d'un discours intitulé: Vue générale des progrès de plusieurs branches des sciences naturelles depuis le milieu du dernier siècle. Nouvelle éd., 7 : i-iv, 1-557, pls. $24-51$. (Rapet et Cie, Paris).

LAcépk̀de, [B. G. E. de la Ville], [G. L. C. F. D.] Cuvier \& [E.] GEOFFroY [-SAINT HilaIRE], 1817. La ménagerie du muséum d'histoire naturelle ou les animaux vivans, avec des observations curieuses faites sur les individus de chaque espece, 2 : i-iv, 1-294. (Tardieu Denesle, Paris).

Ladvocat, J. B., 1749. Lettre sur le rhinocéros, à M.***, membre de la Société Royale de Londres: 1-34. (Thiboust, Paris).

LaNG, E. M., 1961. Beobachtungen am Indischen Panzernashorn (Rhinoceros unicornis). Zool. Gart. Lpz., (N.F.) 25 (6) : 369-409, figs. 1-24.

LEVEY, M., 1956. The eighteenth century Italian schools. National Gallery catalogues: 1-120. (National Gallery, London).

LiNSChOTEN, J. H. VAN, 1644. Iterinarium, ofte Schipvaert naer Oost ofte Portugaels Indien. Inhoudende een beschrijvinghe dier landen, zee-kusten, havens, rivieren, hoecken ende plaetsen, met de gedenckweerdighste historien derselver. Hier zijn bij ghevoeght de conterfeytsels van de havijten ofte drachten, so van de Portugesen aldaer residerende, als van de in-ghebooren Indianen: Ende van hare tempelen, afgoden, huysinghen, manieren, godesdienst, politie, huys-houdinghen ende koop-handel, hoe ende waer die gedreven wort. Als oock van de boomen, vruchten, kruyden, specerijen ende dierghelijcke materialen van die landen: $\mathrm{i}-$-viii, 1-147. (Everhardt Cloppenburch, Amstelredam).

LoISEL, G., 1912. Histoire des ménageries de l'antiquité à nos jours. I. Antiquité, Moyen-âge, Renaissance: i-ii, 1-319. II. Temps modernes (17e et 18e siècles): i-iv, 1-392. III. Epoque contemporaine (19e et $20 \mathrm{e}$ siècles): $i-i v, 1-563$. (Octave Doïn et fils \& Henri Laurens, Paris).

Meder, J., 1932. Dürer-Katalog, ein Handbuch über Albrecht Dürers Stiche, Radierungen, Holzschnitte, deren Zustände, Ausgaben und Wasserzeichen: $\mathrm{i}-\mathrm{xxiv}$, 1-357. (Gilhofer \& Ranschburg, Wien).
MEYER, J. D., 1756. Vorstellûng mancherleij fremder ûnd seltener Thiere, all aûf das richtigste in Küpfer gebracht, der Natur gemäss mit ihren Farben abgebildet, 3 : 1-10, pls. 1-30. (Andreas Bicling, Nürnberg).

MoHR, E., 1957. Das Horn des indischen Rhinoceros unicornis. Zool. Gart. Lpz., (N.F.) 23 (1/3) : 37-45, figs. $1-8$.

MULLER, F., 1876. De nederlandsche geschiedenis in platen. Beredeneerde beschrijving van nederlandsche historieplaten, zinneprenten en historische kaarten; verzameld, gerangschikt, beschreven door F. Muller, 2 (1702-1795) : i-iv, 1-346, i-viii, i-xvi. (Frederik Muller en Co., Amsterdam).

NolL, F. C., 1873. Die Rhinoceros-Arten, I. Zool. Gart., Frankf., (A.F.) 14 (2) : 47-55, 1 fig.

Panofsky, E., 1955. The life and art of Albrecht Dürer, ed. 4 : $\mathrm{i}-\mathrm{xxxii}, 1-320$, figs. 1-325. (Princeton University Press, Princeton, New Jersey).

Parsons, J., 1743. A letter from Dr. Parsons to Martin Folkes, Esq.; president of the Royal Society, containing the natural history of the rhinoceros. Phil. Trans. R. Soc., 42 (470) : 523-541, pls. 1-3.

Pasteur, J. D., 1793. Beknopte natuurlijke historie der zoogende dieren, 1: i-vi, 1-363. (Honkoop \& du Mortier, Leiden).

Petzsch, H., 1935. Das erste indische Nashorn in Deutschland. Aus d. Heimat, Stuttgart, 48 (12) : 372-374, fig. 1.

-, 1954. Das erste in Deutschland zur Schau gestellte Nashorn. Natur und Heimat, 3 (2) : 50-53, figs. $1-5$.

-, 1961. Ein kleiner historischer Nachtrag zu Erna Mohr "Das Horn des indischen Rhinoceros unicornis". Zool. Gart. Lpz., (N.F.) 26 (1/2) : 110-111.

Pignatti, T., 1968. Pietro Longhi : $1-443$, pls. $1-493$. (Alfieri, Venezia).

Plinius Secundus, C., 1769. Des wijd-vermaarden natuurkundigen vijf boeken handelende van de natuure. I. Der Menschen. II. Der viervoetige en kruipende dieren. III. Der vogelen. IV. Der kleine beestjes of ongedierten. V. Der visschen, oester; kreeften enz. Hier zijn bijgevoegd de schriften van verscheidene andere oude schrijvers over de natuur der dieren : $\mathbf{i}-\mathbf{x}$, 1-642, 1-10. (Jan Morterre, Amsterdam).

RAY, J., 1693. Synopsis methodica animalium quadrupedum et serpentini generis. Vulgarum notas characteristicas, rariorum descriptiones integras exhibens: cum historiis \& observationibus anatomicis perquam curiosis: i-xiv, 1-336, i-viii. (S. Smith \& B. Walford, London).

ReYNolds, R. J., 1960. Asian rhinos in captivity. Int. Zoo Yb., 2 : $17-42$.

-, 1960a. White rhinos in captivity. Int. Zoo Yb., 2 : $42-43$.

- , 1964. The black rhinoceros, Diceros bicornis, in captivity. Int. Zoo Yb., 4 : 98-113.

,- 1967 . Some photographs of rhinos exhibited by American circuses between 1855 and 1926. Zool. Gart. Lpz., (N.F.) 34 (6) : $279-292$, figs. $1-5$.

RIDINGER, J. E., 1768. Genrue und richtige Vorstellung der wundersamsten Hirschen sowohl als anderer besonderlichen Thiere, welche von grossen Herren selbst gejagt, geschossen, lebendig gefangen oder gehalten worden: 1-100. (Ridinger, Augsburg). 
SANDERS, ?, 1779. Nachricht vom Rhinoceros in Versailles. Naturforscher, Halle, $13: 1-10$.

Schotius, A., 1603. Hispaniae illustratae seu rerum urbiumq. Hispaniae, Lusitaniae, Aethiopiae et Indiae scriptores varii. Parti editi nunc primum, partim aucti atque emendati, quorum seriem sequem post praefationem pagina exhibet. Tomis aliquot divisi, opera et studio, 1: $i-x i, 1-1189,1-37$. (Apud Claudium Marnium et haeredes Iohannis Aubrij, Francofurti).

SCHREBer, J. C. D. von, 1835. Die Säugthiere in Abbildungen nach der Natur mit Beschreibungen. Fortge- setzt durch Johann Andreas Wagner, 6 : $\mathrm{i}$-xvi, $1-$ 520. (Palm'schen Verlagsbuchhandlung, Erlangen).

TaYloR, B., 1971. Stubbs: $1-220$, pls. $1-137$. (Phaidon Press, London).

Thomas, H. Leigh, 1801. VI. An anatomical description of a male rhinoceros. Phil. Trans. R. Soc., 91 (1) : $145-152$, pl. X.

WolF, J., 1818. Abbildungen und Beschreibungen merkwürdiger naturgeschichtlicher Gegenstände, 1: i-iv, 1-168, pls. 1-36. (Conrad Tyroff, Nürnberg). 